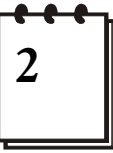

\title{
Pengetahuan Lokal Masyarakat Adat Kasepuhan: Adaptasi, Konflik dan Dinamika Sosio-Ekologis ${ }^{\star}$ )
}

\author{
Rita Rahmawati ${ }^{1}$, Subair ${ }^{1}$, Idris $^{3}$, Gentini $^{2}$, Dian Ekowati ${ }^{2}$, Usep Setiawan ${ }^{2}$
}

\begin{abstract}
Ringkasan
Masyarakat Kasepuhan merupakan masyarakat adat Sunda yang hidup di sekitar Taman Nasional Gunung Halimun - Salak (TNGHS). Masyarakat adat ini mempunyai kekhasan dalam mengatur kehidupan warganya dalam berelasi dengan alam. Melalui konsep pancer pangawinan masyarakat mensandarkan kehidupannya pada keterikatan atas tanah. Permasalahannya sekarang adalah sejak diterbitkannya kebijakan perluasan Taman Nasional melalui SK Menteri Kehutanan Nomor 175/Kpts-II/2003, tanah yang dulu dikuasai oleh masyarakat berubah status menjadi tanah Taman Nasional. Perubahan status tanah tersebut menyebabkan hilangnya akses masyarakat terhadap tanah. Kondisi ini menempatkan masyarakat pada kondisi konflik dengan Pengelola TNGHS. Metode penelitian ini adalah kualitatif dengan paradigma konstruktivisme (Denzin, 2000). Teknik pengumpulan data melalui indepth interview, observasi partisipan, dan Focus Group Discussion (FGD). Hasil dan temuan penelitian menunjukkan adanya pengetahuan lokal masyarakat Kasepuhan dalam hal mengatur kelestarian lingkungan dan bagaimana lingkungan tersebut dapat memberi manfaat untuk kehidupan masyarakat. Misalkan dengan adanya konsep Ibu Bumi, Bapak Langit dan Guru Mangsa, Leuit dan Wewengkon Hutan. Pengetahuan ini telah dikembangkan secara turun temurun dan mengatur relasi masyarakat dengan alam (hutan). Namun pertarungan pengetahuan masyarakat lokal dan pengelola TNGHS telah menyebabkan teralienasinya pengetahuan lokal tersebut. Dengan mengacu pada konsep Escobar (1999), maka dapat disimpulkan bahwa pengetahuan lokal dalam mengelola sumber daya alam dapat dipandang sebagai rezim alam organik, dimana sejak diberlakukannya SK Menteri Kehutanan tentang perluasan TNGHS, masyarakat lokal dengan alam organiknya sedang berhadapan dengan pengelola TNGHS selaku rezim alam negara yang dalam prakteknya bertumpu pada pengetahuan kapitalis dan tekno, dalam memperjuangkan hak akses atas tanah.
\end{abstract}

Katakunci: indigenous knowledge, masyarakat lokal, relasi manusia dan alam

\section{Pendahuluan}

\subsection{Latar belakang}

Masyarakat adat Kasepuhan Sinar Resmi merupakan masyarakat lokal yang ada di wilayah Desa Sirna Resmi, Kecamatan Cisolok, Kabupaten Sukabumi. Lokasinya berada di sekitar Taman Nasional Gunung Halimun Salak. Dari cerita turun-temurun, diketahui bahwa masyarakat kasepuhan adalah sisa-sisa Kerajaan Pakuan Pajajaran. Tercatat, perpindahan pertama yang diketahui terjadi 634 tahun lalu dari Jasinga ke Bogor.

Kehidupan masyarakat adat Kasepuhan mulai terusik beberapa tahun belakangan ini. Masuknya modernisasi yang ditandai dengan pembangunan jalan, listrik, televisi, parabola bahkan pemancar telepon seluler dipasang di 
wilayah ini menyebabkan gaya hidup masyarakat mulai berubah. Gencarnya pengaruh pembangunan ini mulai terasa juga dalam bidang pertanian. Penggunaan pupuk kimia mulai dilakukan oleh beberapa orang penduduk, yang dulu dianggap tabu.

Kasepuhan Sirna Resmi sebenarnya bukan satu-satunya kasepuhan di wilayah ini. Ada tiga (3) kasepuhan yang berpusat di Desa Sirna Resmi, yaitu Sinar Resmi, Cipta Mulya, dan Cipta Gelar. Masing-masing kasepuhan dipimpin oleh seorang pemimpin adat yang disebut Abah. Setiap unit kasepuhan memiliki rumah adat sendiri yang disebut Imah Gede, tempat ketua adat dan istrinya tinggal. Bentuk rumah ini cukup unik. Seluruh tiangnya terbuat dari potongan bambu besar, dinding dari anyaman bambu dan atap dari ijuk yang berwarna hitam serta dengan model yang khas.

Kasepuhan Sinar Resmi sendiri dipimpin oleh Abah Asep. Sebagai pemimpin adat, abah mempunyai kekuasaan yang mutlak terhadap kehidupan masyarakat / pengikutnya (bisa disebut Incu Putu), terutama dalam tata cara mata pencaharian yang bertumpu pada pertanian padi.

Menurut Kusnaka Adimihardja (1989), warga kesepuhan juga menyatakan dirinya sebagai pancer pangawinan. Pancer berarti lulugu atau asal usul, sementara pangawinan berarti ngawin yaitu membawa tombak dalam upacara perkawinan. Upacara perkawinan pun dipandang sebagai menyatunya manusia dengan tanah yang menghidupinya. Sekalipun ada keterikatan terhadap tanah, namun masyarakat Kasepuhan tidak bersikeras untuk menjadikan tanah sebagai kepemilikan. Bagi mereka pengakuan atas tanah adalah adanya akses untuk mengolah tanah tersebut. Hal ini dibuktikan dengan perjalanan sejarah ketika wilayah tempat dimana lahan pertanian mereka dijadikan Taman Nasional Gunung Halimun.

Taman Nasional Gunung Halimun (TNGH) ditetapkan berdasarkan SK Menteri Kehutanan Nomor 288/Kpts/II/1992 dan SK Nomor 282/KP/H-II/1992 tanggal 26 Februari 1992 dengan luas 40.000 ha. Dari luas hutan tersebut, sebanyak $65 \%$ merupakan hutan sekunder dan 35\% adalah hutan primer yang didominasi oleh vegetasi dataran tinggi dan hanya $10 \%$ merupakan hutan dataran rendah (lihat Hadiyanto, 1997: 35; Siregar, 1997: 128). Kawasan ini sebelumnya merupakan hutan lindung dengan luas 39.941 ha yang ditetapkan pada masa pemerintahan Belanda (1924-1939). Kemudian berdasarkan SK Menteri Pertahanan Nomor 40/Kpts/Um/1997 tanggal 11 Januari 1997, kawasan ini diubah statusnya dan ditetapkan sebagai cagar alam.

Masyarakat Kasepuhan bisa menerima keberadaan Taman Nasional, selama mereka masih diberi akses. Sebelum tahun 2003, masyarakat menggarap lahan pertanian mereka di wilayah Perhutani (di sekitar Taman Nasional) - yang dalam konsep mereka termasuk Leweung garapan (hutan garapan) - dengan cara tumpang sari, walaupun harus membayar upeti kepada Perhutani sebesar 
$15-25 \%$ dari hasil tani (cukai Perhutani), tergantung besarnya jumlah hasil tani atau sesuai kesepakatan.

Sejak diterbitkannya Keputusan Menteri Kehutanan Nomor 175/Kpts-II/2003 Tentang Penunjukkan Kawasan Taman Nasional Gunung Halimun dan Perubahan Fungsi Kawasan Hutan Lindung, Hutan Produksi Tetap, Hutan Produksi Terbatas pada Kelompok Hutan Gunung Halimun dan Kelompok Hutan Gunung Salak seluas 113.357 ha di Propinsi Jawa Barat dan Propinsi Banten menjadi Taman Nasional Gunung Halimun - Salak. Sejak SK perluasan ini, luas Taman Nasional Gunung Halimun Salak menjadi 113.357 Ha. Sejak SK perluasan dikeluarkan, kurang lebih ada 300 perkampungan penduduk yang masuk ke dalam wilayah Taman Nasional, termasuk pemukiman dan lahan garapan penduduk Desa Sirna Resmi.

Konsekuensi dari perluasan Taman Nasional ini terhadap hilangnya hak akses masyarakat lokal termasuk masyarakat Kasepuhan untuk dapat menggarap lahan pertanian yang sekian lama telah dikuasainya. Kondisi ini menempatkan masyarakat Kasepuhan berada pada konflik dengan Taman Nasional Gunung Halimun - Salak (TNGHS).

\subsection{Tujuan}

Tujuan studi lapang ini ada tiga, yaitu:

1. Untuk mengetahui bentuk-bentuk pengetahuan lokal

2. Untuk mengetahui dinamika pengetahuan lokal

3. Untuk mengetahui struktur kekuasaan dan konflik pengetahuan

\subsection{Metodologi}

Penelitian dilaksanakan di Kasepuhan Sinar Resmi, Desa Sirna Resmi, Kecamatan Cisolok, Kabupaten Sukabumi. Desa Sirna Resmi merupakan kawasan penyangga Taman Nasional Gunung Halimun - Salak. Bahkan beberapa penduduknya tinggal dan mendiami lahan kawasan Taman Nasional.

Pemilihan lokasi penelitian ini didasarkan atas beberapa pertimbangan:

1. Masyarakat di kawasan ini adalah masyarakat adat Kasepuhan yang masih setia menjunjung tinggi adat dalam kehidupan sehari-hari, khususnya dalam relasi antara manusia dan alam.

2. Masyarakat di kawasan ini bersentuhan langsung dengan kawasan Taman Nasional karena lahan mata pencaharian mereka umumnya berada dalam kawasan sehingga rentan konflik dengan pengelola Taman Nasional.

Penelitian ini menggunakan pendekatan kualitatif. Teknik pengumpulan data dilakukan melalui indepth interview, observasi partisipan, dan Focus Group Discussion (FGD) untuk melakukan refleksi atas pengetahuan masyarakat tentang relasi manusia dan alam serta mengidentifikasi masalah yang sedang dihadapi masyarakat. 
Selanjutnya data-data yang diperoleh tersebut dimaknai dan dikontruksi berdasarkan perspektif subyektif dari peneliti. Penekanan pada penggambaran, pemahaman, dan pemaknaan atas berbagai fenomena tentang relasi manusia dan alam baik secara individu maupun kelembagaan dikonfigurasi dengan menggunakan Analisis "actor in nature" konsepnya Escobar (1999), dimana peran pengetahuan lokal menjadi acuan utama dalam melihat hubungan manusia dan alam, serta konflik yang terjadi dengan Taman Nasional.

\section{Kerangka Konseptual}

\subsection{Pengetahuan Lokal dalam Pengelolaan SDA}

Tumbuh-kembangnya proyek-proyek pembangunan ternyata disertai dengan semakin diacuhkannya keberadaan dan peranan pengetahuan penduduk setempat yang dalam tulisan ini disebut 'pengetahuan lokal'. Kata 'pengetahuan' mengacu pada 'suatu hasil belajar, alasan-alasan dan persepsi atau suatu interpretasi logis seseorang atau sekelompok orang yang digunakan sebagai dasar untuk memprediksi kejadian di masa yang akan datang'. Secara konseptual, pengetahuan lokal adalah kebijaksanaan manusia yang bersandar pada filosofi nilai-nilai, etika, cara-cara dan perilaku yang melembaga secara tradisional (Geriya, 2009). Sementara Haryati Soebadio (Ayatrohaedi, 1986:18 19) mengatakan bahwa local genius adalah juga cultural identity, identitas / kepribadian budaya bangsa yang menyebabkan bangsa tersebut mampu menyerap dan mengolah kebudayaan asing sesuai watak dan kemampuan sendiri.

Pengetahuan lokal secara konseptual terdiri atas dua bentuk, yaitu (1) pengetahuan yang bersifat pragmatis tentang dunia alamiah / objektif yang berlangsung, dan (2) pengetahuan supranatural menyangkut nilai-nilai kultural / dunia subjektif, yang seringkali nilai-nilai ini mempengaruhi atau memodifikasi keinginan-keinginan orang-orang atas sesuatu (Nuraini W. Prasodjo). Pengetahuan pragmatis tentang dunia objektif dapat diamati dengan cara explanatory knowledge dan descriptive knowledge. Sedangkan pengetahuan supranatural orang-orang lokal dapat diamati dengan memperhatikan bentukbentuk dasar-dasar aturan, norma-norma, nilai-nilai yang dihasilkan oleh budaya, agama dan moral. Tetapi pengetahuan saja seringkali tidak cukup mendorong seseorang atau sekelompok orang untuk mengambil keputusan atau melakukan aksi nyata. Ada beberapa faktor lain yang turut mempengaruhi terwujudnya suatu aksi, yaitu: (1) kondisi dan bentuk-bentuk dasar aturan nilai yang dihasilkan oleh budaya, agama, dan moral, (2) keadaan ekonomi, dan (3) intervensi kebijakan, baik berupa dukungan sumber daya material maupun pengetahuan.

Pengetahuan lokal yang unik pada suatu masyarakat atau budaya disebut indigenous knowledge. 
Indigenous knowledge is the local knowledge that is unique to a given culture or society. It is the basis for agriculture, health care, food preparation, education, environmental conservation, and a host of other activities. Much of such knowledge is passed down from generation to generation, usually by word of mouth. Indigenous people have a wide knowledge of the ecosystem they live in and ways to ensure that natural resources are used sustainable. Therefore, indigenous knowledge which has been accumulated over centuries has potential value for sustainable development. It can also help other people learn how to live in harmony with nature and the environment in a sustainable fashion'. (Diadaptasi dari Indigenous Knowledge and Sustainable Development, Sri Lanka Centre for Indigenous Knowledge, University of Sri Jayewardenapura, 1996, p. vii-viii).

Istilah pengetahuan lokal berbeda dengan kearifan lokal. Kearifan lokal (local wisdom) adalah sebuah tema humaniora yang diajukan untuk memulihkan peradaban dari krisis modernitas. Ia diunggulkan sebagai "pengetahuan" yang "benar" berhadapan dengan standar "saintisme" modern. Sains modern menganggap unsur "nilai" dan "moralitas" sebagai unsur yang tidak relevan untuk memahami ilmu pengetahuan. Bagi sains, hanya fakta-fakta yang dapat diukurlah yang boleh dijadikan dasar penyusunan pengetahuan. Kearifan lokal adalah hujah (argumen) untuk mengembalikan "nilai" dan "moralitas" sebagai pokok pengetahuan. Yang khas dari pandangan kearifan lokal adalah nilai dan moralitas itu tidak dicari melalui deduksi etika (misalnya dengan memeriksa asumsi suatu ajaran tentang "yang baik" dan "yang buruk", "larangan" dan "suruhan"), atau dengan mencarinya dalam realitas peristiwa yang sedang dihadapinya (misalnya, "mengekstrak" prinsip-prinsip moral suatu peristiwa). Kearifan lokal berdasarkan kebenaran pengetahuannya pada ajaran-ajaran tradisional yang sudah jadi, dan hampir tidak mempersoalkan lagi kandungan politik ajaran-ajaran tradisional itu.

Dalam konteks penelitian ini, pengetahuan lokal adalah indigenous knowledge, dimana pengetahuan lokal yang hendak dilihat adalah pengetahuan yang erat hubungannya dengan aspek pengelolaan sumber daya alam dan mata pencaharian atau sistem nafkah. Secara konseptual, Berkes (1995) mengemukakan bahwa pengetahuan lokal dalam aspek ekologis dan juga pengetahuan lokal tentang sistem nafkah, sangat penting peranannya pada konservasi biodiversity, dalam arti bahwa dengan sistem pengetahuan tersebut akan diperoleh '...suistainable use for human benefit without compromising the interests of future generation'. Menurut Berkes, kekuatan utama sistem pengetahuan lokal dalam aspek ini adalah:

1. Self-interest, dalam arti pengetahuan lokal menjadi kunci penting upaya konservasi, karena kekuatannya datang dari 'dalam' dan bukan dari 'luar'.

2. Sistem pengetahuan yang akumulatif, dalam arti bahwa pengetahuan lokal merupakan akumulasi atas pola adaptasi ekologis komunitas lokal yang telah berlangsung berabad-abad. 
3. Pengetahuan sangat potensial untuk membantu mendesain upaya konservasi sumber daya yang efektif, karena dukungan lokal dan tingkat adaptasi serta pertimbangan practicability-nya yang tinggi.

\subsection{Pengetahuan Lokal vs Pembangunan: Konflik Ideologis}

Dalam perkembangannya saat ini, pengetahuan lokal semakin kehilangan eksistensinya, kecuali di beberapa wilayah adat. Itupun dalam keadaan yang 'kritis'. Menurut Hobart (1993), berbagai proyek pembangunan yang dirancang secara top down tanpa melibatkan partisipasi penduduk setempat sehingga gagal mengakui secara tepat pentingnya dan berpotensinya pengetahuan lokal. Sebaliknya, proyek-proyek pembangunan sering melibatkan asumsi bahwa pengetahuan ilmiahlah yang lebih superior, atau 'lebih benar' daripada pengetahuan lokal. Pengalaman sejarah membuktikan bahwa sebagai implikasi lebih lanjut dari hegemoni pengetahuan ilmiah ini dalam proyek-proyek pembangunan, adalah berbagai konsekuensi tidak terduga dan kemerosotan kondisi lingkungan hidup serta kesejahteraan penduduk setempat bermunculan.

Menurut Dharmawan (2007), saat ini desa (lokalitas) telah menjadi ajang perebutan tarik-menarik kepentingan sosial-politik dan ekonomi yang menjadikan eksistensinya tidak selalu bebas dalam menentukan arah perkembangannya ke depan. Dari perspektif world-system theory, gejala artikulasi (perebutan kekuatan) sistem-sistem pengaturan dimana sistem sosial lokalitas yang diwakili oleh indigenous civilization terus didesak oleh kekuatan westernglobal world yang sangat menekan. Tekanan tersebut berlangsung melalui ekspansi-ekspansi "sistem pengetahuan Barat" (yang mendesak sistem pengetahuan lokal), "nilai-budaya modernitas ala Eropa Barat" (yang menggusur cara hidup khas-lokalistik), serta "sistem-ekonomi kapitalisme" yang melaju seiring dengan perluasan kapital dari Trans-National Corporations (TNCs) yang mendesak perekonomian lokal.

Escobar (2005) menyebutkan bahwa 'rezim pembangunanisme' yang berjalan menurut "logika" teori modernisasi dianggap telah menjadi kekuatan kolonialisme baru tidak saja sebagai powerful mechanism for production and economic management (TNCs) namun lokalitas juga telah menjadi obyek-obyek baru penetrasi ilmu pengetahuan ala Western (TNKs). Penetrasi cara berpikir (yang serba pertumbuhan, serba investasi asing, serba akumulasi ekonomi dan serba ekspansi-kapital) itulah yang selanjutnya kelak menghasilkan dominasidominasi budaya dalam cara berpikir yang melenggangkan dan melanggengkan dominasi kekuasaan-kekuasan politik lokal ala kelembagaan kapitalistik Barat (pada tatanan pengaturan lokal). Penetrasi sistem pengetahuan Barat yang sangat Euro-centrism terhadap indigenous knowledge melalui kekuatan TNKs sangat mempengaruhi (depressing-effect) keberdayaan pengaturan lokal (lihat Silitoe, 1998; Nygren, 1999). Ketidakberdayaan struktur kelembagaan lokal (pemuka adat, aturan adat, hukum adat) dalam mengatur dan bernegosiasi 
dengan kekuatan luar, adalah keprihatinan besar yang sangat mengancam eksistensi lokalitas.

Peta Konflik antara kedaulatan pengetahuan lokal dengan pengetahuan luar (TNKs, TNCs, dan TNSs) dapat digambarkan dalam bagan di bawah ini.

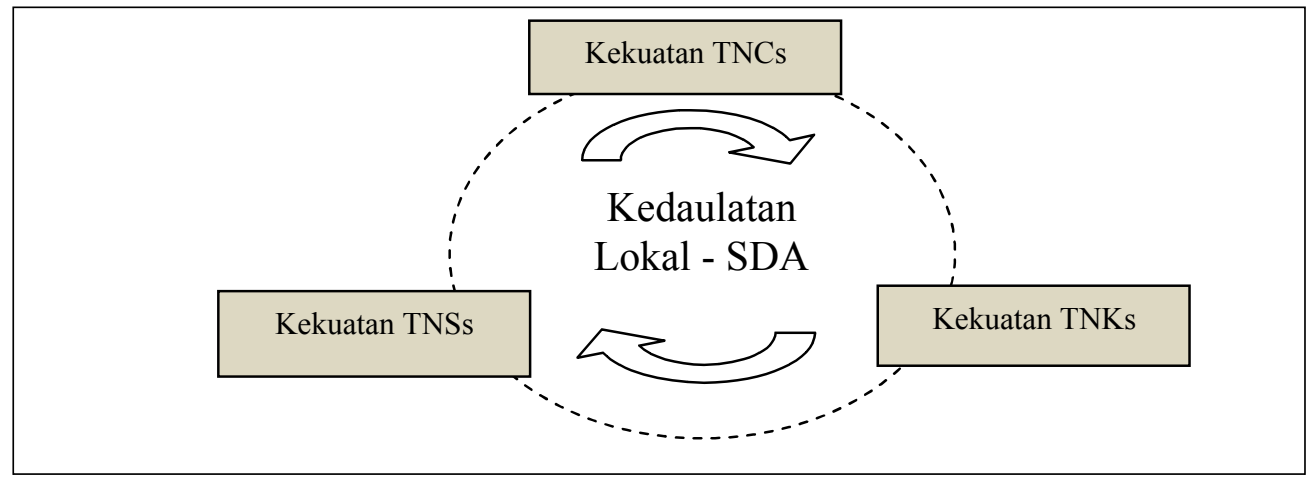

Gambar 1 Peta konflik antara kedaulatan pengetahuan lokal dengan pengetahuan luar (TNKs, TNCs, dan TNSs).

(Sumber: Dharmawan, 2007)

Dalam kerangka seperti itu, otoritas lokalitas di banyak kawasan dunia ketiga menyerah pasrah dan menjadi tidak berdaulat (authority-loss) lagi atas SDA. Kehilangan kedaulatan ini jelas mengubah the whole landscape of livelihood system secara totalitas sehingga struktur nafkah lokal (pedesaan) menjadi sangat mengenaskan. Dalam hal ini Escobar $(1998,1999)$ memperkenalkan konsep 'tiga-alam' untuk melihat kekalahan sistem pengaturan SDA lokal. Ketiga alam itu adalah: "alam organik" (sistem alam yang dipelihara oleh komunitas lokal) yang menjadi domain kekuatan lokalitas dalam rezim tata-kelolaSDA. Kedua, "alam kapitalis" yaitu sistem alam atau SDA yang dikolonisasi oleh kekuatan kapitalisme, dan ketiga adalah "alam teknologis" yaitu sistem alam yang dikuasai oleh pemilik teknologi maju (Barat). Dalam konsepsi Escobar, hanya alam organiklah yang sepenuhnya berada dalam kekuasaan lokal. Kedua alam lainnya berada di domain tata-kelolaSDA ala modernitas-Barat yang sarat dengan muatan kepentingan global-transnasionalisme.

Dari gambaran empirik itu, sangat tampak jelas bahwa lokalitas (desa) sebagai social container struktur dan budaya lokal serta memiliki kekhasan pengaturan SDA menghadapi kerentanan yang luar biasa saat mereka harus menghadapi globalisme kapital, global knowledge system dan konspirasi antarnegara yang mengepung dari segala sudut perhatian. Menurut Dharmawan (2007), kerentanan tersebut bisa berakibat sangat fatal dan menjelma ke dalam dua bentuk dilema, yaitu: (1) dilema ketergantungan (ketergantungan sumber nafkah, informasi, budaya) dan (2) dilema kehilangan identitas budaya lokal 
melalui mekanisme pelumpuhan struktur lokal atau peleburan identitas kelembagaan lokal kepada identitas global yang sangat dominan.

Dengan tetap berasumsi pada bekerjanya tiga pusaran arus globalisme yang menghempas desa atau lokalitas, maka Dharmawan (2007) menyusun teoretisasi tentang pengelolaan SDA oleh komunitas lokal. Teoretisasi tersebut mengacu pada kerangka pemikiran Friedman (1999) yang mengemukakan bahwa kecenderungan global menawarkan dua ranah pemikiran tentang "identitas struktur kekuasaan" di wilayah kekuasaan pengaturan dan "identitas budaya tempatan" di wilayah sistem sosiobudaya lokal.

Dalam teoretisasi Friedman (1999), ranah identitas struktur kekuasaan mengenal dua kutub yang saling berseberangan, yaitu "self-directed regime" (kedaulatan lokal) di satu kutub dan "other directed regime" (keterjajahan oleh kekuatan asing) di kutub yang lain. Kedua kutub dihubungkan oleh continuum of identity dimana di antara keduanya ditemukan variasi-variasi identitas struktur kekuasaan dan otoritas turunannya. Sementara itu dikenal pula dua kutub lain dalam ranah identitas sistem budaya, yaitu kutub "kosmopolitanisme" (keterbukaan total) yang bercirikan interkulturalisme dan multikulturalisme di satu sisi, dan kutub "komunitarianisme" (ketertutupan budaya total) yang bercirikan identitas kultural "enclave" (ciri budaya sangat homogen) di sisi lainnya. Kedua kutub membangun identity of culture continuum yang di antara kedua kutub dapat ditemukan variasi-variasi identitas budaya turunannya.

Dengan menerapkan pemikiran Friedman di atas, Dharmawan (2007) menyusun empat kombinasi ekstrem tata-kelolaSDA maupun identitas ekstrem pengembangan sistem pengetahuan dan nilai budaya lokal, yang disebutnya ruang-ruang tata pengaturan SDA. Dalam tulisan ini, istilah ruang tersebut diganti menjadi model karena setiap ruang adalah model proyeksi teoritis dari kemungkinan-kemungkinan pengelolaan SDA lokal ketika bersentuhan dengan pembangunan sebagai unsur eksternal. Model tersebut adalah:

1. Model I, adalah model dimana pengelolaan SDA mengandalkan strukturstruktur kelembagaan dan aturan-aturan lokal yang sangat otonom sifatnya. Segala kekuatan asing (TNCs, TNKs, maupun TNSs) tidak dapat menembus isolasi model I sehingga struktur otoritas pengelola SDA berkesan bercirikan "lokalisme defensif". Nilai budaya dan sistem pengetahuan lokal yang kuat membuat sistem tata-kelola SDA sangat berciri lokal, sehingga membentuk sebuah enclave sistem budaya yang sangat khas.

2. Model II, adalah model dimana kedaulatan lokal atau otonomi lokal hanya terjadi dalam hal olah-otoritas pengelolaan SDA saja. Hingga taraf tertentu TNCs dan TNSs tidak mampu mengubah tatanan pengelolaan SDA lokal. Namun, sifat keterbukaan masyarakat dan tiadanya filter budaya yang kuat (bersifat kosmopolit atau permisif terhadap nilai-nilai asing) telah menyebabkan inter-cultural-influx mengarus masuk dengan kekuatan cukup tinggi pada model ini. Derasnya arus keterbukaan 
memberikan akses yang sangat besar bagi masuknya sistem-sistem pengetahuan, ideologi dan tata-nilai budaya asing (TNKs) ke kawasan lokal. Intrusi TNKs yang terus menerus, hingga taraf tertentu mampu melumpuhkan sistem budaya lokal sehingga menghasilkan hibriditas budaya pada masyarakat tempatan.

3. Model III, adalah model dimana modernitas-Barat yang dibawa oleh gerakan modernisasi (termasuk modernisasi pemerintahan lokal) via berbagai kegiatan pembangunan (kerjasama TNCs dan TNSs), telah mampu mengubah struktur-struktur atau tatanan-kelembagaan pengelolaan SDA lokal. Otoritas asli pengelola SDA lokal tidak lagi mampu dan berdaya (lumpuh dan terdistorsi) sehingga digantikan secara totalitas oleh struktur pengelolaan SDA bentukan dari luar. Selain itu, sifat masyarakat yang permisif (kosmopolit) ditambah dengan tidak bekerjanya filter-filter budaya secara sempurna, telah menyebabkan rusaknya sistem budaya lokal. Dengan kehancuran ini, maka dengan sangat mudahnya TNKs membangun hibriditas budaya di masyarakat tempatan.

4. Model IV, adalah model dimana kelembagaan bentukan pengelolaan SDA (akibat kekuatan proses-proses modernisasi-kapitalisasi oleh TNCs dan TNSs) telah mengubah lanskap kelembagaan pengaturan SDA di wilayah tempatan. Komunitas lokal dan tata-pengaturan SDA lokal tidak berdaya menghadapi tekanan TNCs dan TNSs, sehingga sistem pengelolaan SDA secara keseluruhan mengikuti cara-cara yang diintroduksikan dari luar sistem sosial lokal. Namun, pada model ini filter-filter budaya masih terjaga dengan baik, sehingga orientasi nilai budaya tempatan (lokal) masih dapat operasional bagi komunitas lokal. Dalam hal ini dapat dikatakan bahwa struktur pengelolaan SDA telah terkolonisasi oleh struktur dan mekanisme bentukan dari luar.

Menurut Friedman (1999), bahwa untuk keluar dari kekuatan hegemonik TNSs dan TNCs dan arus-arus pikiran Eurocentrism (TNKs) yang menekan itu, maka diperlukan adanya perubahan radikal berpendekatan "strukturalismepembebasan" terhadap komunitas lokal (desa). Strategi "reteritorialisasi kedaulatan lokal" dalam hal ini dipandang dapat berfungsi sebagai penawar proses-proses deteritorialisasi sistem sosial-ekonomi dan budaya lokalitas akibat globalisme. Strategi tersebut berpusat pada keunggulan lokal dan menjadi satusatunya pilihan-solusi dari "mazhab kekuasaan" bagi sistem lokal untuk keluar dari kolonisasi TNCs, TNKs, dan TNSs. Hanya dengan pendekatan reteritorialisasi ("kembali berdaulat") itulah, sistem-sistem lokal dapat tertolong dari pusaran-pusaran kekuasaan yang sangat mematikan di masa kini dan mendatang. 


\section{Analisis Hasil Penelitian}

\subsection{Karakteristik Umum Wilayah Penelitian}

Secara administratif, Desa Sirna Resmi berada dalam wilayah Kecamatan Cisolok, Kabupaten Sukabumi yang merupakan wilayah penyangga Taman Nasional Gunung Halimun - Salak (TNGHS). Tipologi desa ini adalah desa di sekitar hutan dan desa terisolasi, dengan posisi desa ditinjau dari jarak dengan lokasi ibukota kecamatan dan kabupaten, sebagai berikut:

Tabel 1. Jarak lokasi desa dengan ibukota kecamatan dan ibukota kabupaten

\begin{tabular}{lc}
\hline \multicolumn{1}{c}{ Jarak Desa Sirna Resmi dengan Pusat Pemerintahan } & Jarak / Lamanya \\
\hline Dari lokasi ke ibukota kecamatan terdekat & $23 \mathrm{~km}$ \\
\hline Lama tempuh ke ibukota kecamatan terdekat & $1 \mathrm{jam}$ \\
\hline Dari lokasi ke ibukota kabupaten terdekat & $33 \mathrm{~km}$ \\
\hline Lama tempuh ke ibukota kabupaten terdekat & $1.5 \mathrm{jam}$ \\
\hline
\end{tabular}

Sumber: Monografi Desa Sirna Resmi Tahun 2007

Iklim wilayah ini memiliki curah hujan yang cukup tinggi, dengan lama bulan hujan 5 bulan. Suhu rata-rata di tiap desa juga cukup dingin berkisar dari $20^{\circ} \mathrm{C}$ sampai $30^{\circ} \mathrm{C}$. Selain suhunya yang dingin, seringkali desa ini juga diselimuti kabut. Keadaan cuaca yang dingin, berkabut dan curah hujan tinggi tersebut disebabkan karena lokasi desa tersebut berada pada dataran tinggi dan sekitar hutan. Ketinggian tempat di desa tersebut berkisar dari 600 meter di atas permukaan laut (mdpl) sampai $1600 \mathrm{mdpl}$.

Luas wilayahnya adalah $4.917 \mathrm{Ha}$., yang sebagian besarnya berupa hutan lindung $(4000 \mathrm{Ha})$. Sebagian lahan pertanian masyarakat ada di wilayah taman nasional yang dulunya berstatus tanah milik Perhutani. Pada saat masih dikuasai Perhutani, masyarakat menanam tanaman pangan secara tumpang sari di sela-sela tanaman inti milik perhutani.

Luas kepemilikan lahan masyarakat sulit diukur secara ukuran universal mengingat masayarakat lokal mempunyai satuan ukuran sendiri, seperti untuk sawah mereka menggunakan satuan ukuran jumlah bibit atau hasil panen padi yang dihasilkan. Sedangkan untuk pekarangan atau kebun, tidak ada satuan pembanding sama sekali.

Pola kepemilikan lahan masyarakat adalah berasal dari warisan. Ketika menikah, penduduk baik laki-laki maupun perempuan telah diwarisi tanah oleh orang tuanya. Demikian pula jika orang tua meninggal, tanah akan diwariskan secara merata. Adapun pola penggunaan lahan umumnya digunakan untuk pekarangan, sawah, dan kebun / dukuh. Lahan untuk areal pertanian biasanya digarap sendiri. Jika digarap orang lain, digunakan sistem maro, yaitu hasil panen dibagi dua setelah dipotong modal. Kehidupan pertanian (ladang 
dan sawah) masih menjadi ciri utama kehidupan masyarakat di sekitar TNGHS ini.

Masyarakat Kasepuhan umumnya tidak memiliki tanah pribadi di luar kawasan, sekalipun punya letaknya di dalam kawasan. Mata pencaharian utama masyarakat Kasepuhan adalah pertanian padi baik huma maupun sawah. Ada masyarakat yang bermata pencaharian sebagai petani dan ada yang sebagai buruh tani. Buruh tani di Kasepuhan mempunyai tanah garapan (sawah / huma) tapi jumlahnya sedikit, maka dia menjadi buruh setelah tanahnya selesai digarap, atau menjadi buruh untuk tanahnya sendiri. Buruh murni tidak ada, yang betul-betul buruh dan tidak punya tanah. Upah buruh tani sistemnya 5:1 untuk padi, sedangkan kalau dibayar dengan uang sebesar Rp. 30.000 per hari dari jam 08.00-15.00

Dalam hal menggarap lahan pertanian padi, kedudukan laki-laki dan perempuan (suami dan istri) seimbang, saling bekerja sama, ada bagian yang harus dikerjakan oleh laki-laki dan ada bagian yang harus dikerjakan oleh kaum perempuan. Misalnya dalam hal ngasek (melobangi tanah), tugas laki-laki adalah melobangi tanah, selanjutnya perempuan yang memasukan padinya ke lubang.

Pada saat habis panen padi, tanah ditanami oleh palawija (ketimun, buncis, jagung, ikan), sampai datang masa menanam padi lagi. Tanaman padi utama adalah huma, sedangkan sawah hanya pendamping.

Desa Sirna Resmi merupakan wilayah pusat kasepuhan. Penduduknya tinggal dalam kampung-kampung kecil yang biasanya terdiri dari 10-30 rumah membentuk pola pemukiman the farm village type menurut istilah Smith dan Zopf (1970) dengan ibukota desa sebagai perkampungan terbesar. Biasanya satu kampung itu terdiri dari satu keluarga besar. Posisi setiap kampung dikelilingi oleh lahan sawah pertanian dan perkebunan. Setiap kampung dihubungkan oleh jalanan setapak yang tersusun dari batu gunung dengan rapi. Terdapat sekitar 23 kampung di desa ini. Sementara berdasarkan wilayah pemerintahan, terdapat tujuh dusun, yaitu Sirna Resmi, Cibongbong, Cikaret, Cimapag, Situ Murni, Cipulus, dan Cipta Gelar. Terdapat tiga dusun yang berada di wilayah TNGHS yaitu Dusun Cipulus, Cipta Gelar, dan Situ Murni.

Di wilayah ini terdapat tiga (3) kasepuhan yaitu Kasepuhan Sinar Resmi yang dipimpin oleh Abah Asep, Kasepuhan Cipta Mulya yang dipimpin oleh Abah Uum dan Kasepuhan Cipta Gelar yang dipimpin oleh Abah Ugi. Pemimpin adat tiga kasepuhan ini masih mempunyai hubungan darah, karena berasal dari keturunan yang sama (dulunya kasepuhan hanya satu). Menurut cerita masyarakat kasepuhan, kasepuhan ini akan terpecah menjadi tujuh di masa yang akan datang.

Sebagai satu kesatuan adat, satu kasepuhan memiliki anggota yang tersebar di seluruh wilayah di sekitar desa ini. Bahkan tidak sedikit yang berasal dari luar pulau Jawa. 


\subsection{Bentuk-Bentuk Pengetahuan Lokal}

Di tengah gempuran modernisasi dengan masuknya berbagai pengetahuan dan teknologi Barat, seperti parabola, televisi bahkan telepon seluler membuat arus informasi luar tidak lagi bisa dicegah. Pengaruh globalisasi ini semakin terasa dan mengubah gaya hidup masyarakat. Beberapa rumah penduduk tidak lagi bercirikan model rumah adat yang berdinding bambu dan beratapkan ijuk, namun seiring masuknya modernisasi, beberapa rumah penduduk sudah mulai menggunakan atap genteng dan dinding beton, walaupun itu hanya beberapa. Bahkan pupuk kimia yang dulu tabu, sekarang sudah mulai digunakan oleh beberapa orang.

Namun demikian, sekalipun arus modernisasi sangat deras menerpa kehidupan masyarakat kasepuhan, namun kesetiaan terhadap tradisi masih terus dijaga, seperti hanya menanam jenis padi tertentu, pantang menjual beras, hingga perintah untuk berpindah tempat masih terus ketat dijalankan. Semua tradisi tersebut selalu dikaitkan dengan keberadaan perintah dari leluhur (wangsit), yang terus dipelihara oleh abah dan pengikutnya. Pengingkaran terhadap wangsit akan berdampak pada hukuman leluhur berupa "kabendon". Dipercaya oleh masyarakat kasepuhan, bahwa apabila melanggar hukum adat akan kena sanksi adat yang disebut kabendon, yang berupa terkena penyakit yang tidak dapat disembuhkan secara medis. Karena kena kabendon, seseorang misalnya dapat tersesat di hutan hingga meninggal. Orang bisa terbebas / terlepas dari kabendon apabila ingat akan kesalahan dan pelanggaran yang diperbuat, dan segera mohon ampun dan minta maaf pada abah dan berjanji untuk tidak mengulanginya lagi.

Masih kuatnya kepercayaan terhadap leluhur, wangsit dan ketakutan akan kabendon inilah yang membuat berbagai tradisi dan pengetahuan lokal tetap terpelihara dan dijalankan. Kalaupun ada perubahan seperti kepemilikan TV, HP, mobil bahkan perubhan pada bentuk fisik rumah dan penggunaan pupuk kimia semua itu dizinkan oleh leluhur melalui restu abah. Selama abah merestui maka leluhur dianggap merestui, karena landasan restu abah adalah restu leluhur.

Tradisi kasepuhan yang utama adalah dalam mata pencaharian, yang bertumpu pada pertanian padi. Pola pertanian tradisional yang ditunjukkan warga kasepuhan memiliki hubungan yang sangat erat antara praktek pertanian, institusi sosial, sistem kepercayaan dengan unsur-unsur alam seperti tanah, air, udara, sinar matahari, cuaca dan lain-lain.

Sejak berabad yang lalu, secara turun-temurun dari generasi ke generasi, mereka telah mengenal dan bergaul secara akrab dengan lingkungan alamnya. Pergaulan, pengetahuan, imajinasi, dan pemahamannya tentang hakekat alam semesta melahirkan kosmologi kasepuhan. Di kalangan warga kasepuhan, terdapat pandangan bahwa alam semesta itu sebagai suatu sistem yang teratur 
dan seimbang. Alam semesta akan tetap ada selama elemen-elemennya masih terlihat dan terkontrol oleh hukum keteraturan dan keseimbangan yang dikendalikan oleh pusat kosmiknya (lihat Kusnaka Adimiharja, 1997: 81). Kosmologi itu terangkum dalam pancer pangawinan yaitu melaksanakan sara, nagara, dan mokaha. Sara adalah agama, nagara adalah pemerintahan dan mokaha adalah keselamatan atau kasepuhan. Sara, nagara dan mokaha harus bersatu. Setiap keputusan yang diambil oleh kasepuhan harus mengacu pada prinsip ' $k u d u$ nyanghulu ka hukum, nunjang ka nagara, mufakat jeung balarea' (harus mengacu kepada hukum, mendukung negara, mufakat dengan orang banyak). Dalam hal memahami keberadaan Tuhan, konsep kasepuhan mengajarkan 'pur kuntu pur kurungan, nganti jeung gusti geura ngaraga jeung nukawasa, sara nagara mokaha, ngajina kudu ngajirim' (jika melakukan kesalahan dari aturan adat maka akan terjadi matak/kualat atau istilahnya kabendon).

\section{Ibu Bumi, Bapak Langit, dan Guru Mangsa vs Program Intensifikasi Pangan}

Mata pencaharian utama masyarakat adalah bertani baik di ladang maupun sawah. Pola pertanian masyarakat kasepuhan bertumpu pada pengtahuan yang turun temurun mengenai cara bertani yang menggantungkan pada keberadaan kepercayaan terhadap alam. Konsep tentang Ibu Bumi, Bapak Langit, dan Guru mangsa.

Masyarakat kasepuhan menanam padi-padian lokal yang mereka sebut pare ageung. Mereka mengenal tidak kurang dari 100 spesies padi. Namun umumnya masyarakat memanfaatkan sekitar 50 spesies. Masyarakat Kasepuhan Sirna Resmi masih memelihara cara bertani tradisional. Mereka menggarap tanah dan menanamnya setahun sekali. Hal itu mereka lakukan demi penghormatan kepada Ibu Bumi. 'Masa, Ibu dipaksa melahirkan dua kali setahun. Benar saja,' demikian prinsip Abah Asep. Bumi ini adalah makhluk hidup. Karena itu tradisi mengajarkan tentang ritus pertanian. Sebelum mengolah tanah, mereka lakukan upacara. Menurut keyakinan mereka, untuk mengolah tanah perlu pamit dulu atau permisi karena bumi ini adalah makhluk yang telah dikotori. Itulah yang mereka lakukan.

Secara resmi agamanya Islam dan ada sebuah masjid di tengah kampung. Namun mereka masih memberikan ritus atau sesajian buat Dewi Sri. Padi dalam konsep kasepuhan dimaknai sebagai Dewi Sri (Ibu), sehingga mulai dari tanam sampai panen dan memasak dan memakannya menggunakan tata cara penghormatan tertentu. Ada banyak upacara adat yang berhubungan dengan pertanian padi, misalnya pada saat akan memulai kegiatan pertanian harus meminta izin terlebih dahulu kepada abah. Setelah abah mendapatkan wangsit barulah memberikan izin kepada incu putu untuk melakukan kegiatan pertanian secara serentak pada bulan tertentu yang sudah ditetapkan oleh adat. Dalam setiap kegiatan pertanian juga terdapat berbagai macam upacara ritual, misalnya pada saat memilih bibit, dilakukan upacara ritual dengan cara membakar 
kemenyan dan melantunkan doa, begitupun pada saat menabur benih. Pada saat membuka ladang, selain membakar kemenyan juga menyediakan tumpeng.

Upacara ritual yang mirip perlakuannya di dalam ritual manusia adalah pada saat mapag pare nyiram (yaitu saat pohon padi mulai berbunga). Pada upacara ini tanaman padi diperlakukan seperti wanita yang sedang hamil 7 bulan, karena itu upacara juga diwarnai dengan penyediaan rurujakan 7 macam rujak, bubur merah dan putih, dan dilakukan doa selamatan seperti pada manusia, seperti membaca surat Yusuf dan Surat Maryam. Tujuan dari upacara ini agar padi yang mulai berbuah tadi selamat dan menghasilkan biji padi yang banyak. Selanjutnya, sebelum panen, setelah panen (nganyaran padi) juga dilakukan upacara berupa penyediaan kemenyan, kopi, rokok dan kue serta doa-doa. Upacara terbesar adalah pada saat memasukkan padi ke lumbung yang disebut upacara seren tahun. Upacara ini dilakukan selama 3 hari - 3 malam oleh seluruh incu putu yang langsung dipimpin oleh abah.

Bapak Langit menunjukkan adanya pengetahuan lokal yang dilandaskan pada kejadian di alam semesta (langit) dalam hal mengolah tanah pertanian, yaitu dalam menentukan waktu untuk menggarap lahan melihat pada bintang kerti dan kidang. Kerti dan kidang adalah rasi bintang yang dilihat di langit pada malam hari. Kerti adalah bintang ngaronyok (kumpulan bintang), kidang adalah bintang waluku ( $n u$ tilu) bentuknya seperti layang-layang. Berlakunya hukum alam Kerti dan Kedang: dimana-mana tina kerti kudu turun besi, dimana-mana tina besi kudu turun...; dimana-mana timbul kidang kudu turun kujang (artinya kalau bintang kerti sudah terlihat maka petani harus sudah menyiapkan peralatan cangkul, parang dan lain-lain, dan jika bintang kidang sudah terlihat maka petani sudah diperbolehkan untuk turun ke sawah atau huma untuk menggarap lahannya).

Guru Mangsa yaitu berguru pada alam semesta dalam hal menentukan waktu kapan boleh bertani dan tidak. Tujuannya adalah ngudag akuan (mengejar hak atas tanah). Bintang kerti menjadi tanda awal untuk menggarap lahan. Meskipun hujan belum juga turun, mereka tetap menanam sesuai dengan pakem-pakem tradisi. Bulan September-April adalah hak untuk petani sedangkan Mei sampai Agustus adalah hak bagi makhluk lain seperti hama dan lain-lain (tidak boleh disebut). Setelah menanam padi, lahan pertanian dipagar dengan ajian (doa): 'ulah arek comokot kana tetendenan aing, ulah heureuy, ulah badeur' (jangan ngambil simpanan aku, jangan main-main, jangan nakal). Pemagaran ini didasarkan pada prinsip 'opat panahap kalima pancar' (empat arah mata angin, Barat-Timur-Selatan-Utara, dan satu pusat), yang sebenarnya mengandung siloka berbeda-beda tetapi satu tujuan.

Cara-cara pengetahuan lokal seperti digambarkan di atas dalam menentukan waktu mengolah lahan dan hanya satu kali dalam satu tahun pengolahan lahan untuk pertanian padi dilakukan walaupun berada pada lahan sawah. Hal ini tentu sangat bertentangan dengan pengetahuan pertanian modern dengan prinsip intensifikasinya, dimana prinsipnya lahan pertanian dapat digarap lebih 
dari satu kali bahkan kalau perlu tiga kali dalam setahun dalam rangka mengejar produktivitas.

Masyarakat kasepuhan pernah mengalami tekanan berat pada masa Revolusi Hijau. Petugas datang dan mewajibkan mereka menanam dua kali setahun di lahan sawah. Mereka tahu, hal itu tidak sesuai dengan tradisi atau perintah nenek moyang (karuhun). Tetapi mereka tidak berani menolak. Lalu mereka bersikap, terserah kepada siapa pun yang mau mengikutinya. Memang, ada yang mengikuti. Dari pengalamannya, ternyata pola tanam dua kali setahun membuat tanah semakin kurus. Hasil pada tahun pertama memang baik. Tetapi pada tahun-tahun berikutnya, hasilnya semakin merosot. Bahkan modal yang keluar untuk beli pupuk atau pestisida lebih besar dari hasil yang mereka peroleh. Pupuk-pupuk memang menyuburkan padi, tetapi mengurangi unsur hara. Menurut konsep pertanian modern, semakin lahan sering dimanfaatkan, maka produktivitas semakin tinggi. Agar lahan tersebut dapat berproduksi dengan baik, maka digunakan pupuk kimia. Namun ternyata hasil penelitian kemudian membuktikan bahwa penggunaan pupuk kimia yang semakin sering dilakukan menyebabkan tanah kecanduan terhadap pupuk tersebut dan semakin lama membutuhkan dosis yang semakin tinggi (lihat Escobar, 1999).

Ada buktinya. Semestinya, kata Abah Asep, bila orang tanam dua kali setahun, lumbungnya menjadi dua. Tetapi hal ini tidak terjadi. Malahan lumbung pun kosong. Karena hasil padi yang diperkenalkan oleh pemerintah segera dijual karena tidak tahan lama. Pada masa paceklik mereka harus membeli padi lagi. Sedangkan masyarakat yang pakai pola setahun sekali menyimpan padi dengan rapi di lumbungnya yang disebut Leuit hingga masa panen berikut. Bahkan padi lokal bisa bertahan hingga berpuluh-puluh tahun. Oleh karena itulah mereka tetap mengikuti kebiasaan warisan nenek moyang. "Ini tradisi, barokahnya sudah pasti," kata Uwa Amir Buchori, sekretaris kasepuhan.

Konsep pertanian modern "intensifikasi" bertentangan dengan cara-cara masyarakat lokal menggarap lahannya. Menurut Abah Asep 'Kalau dihitung berdasarkan produktivitas, sebenarnya hasil tani abah rugi. Tapi yang dikejar oleh masyarakat kasepuhan bukan produktivitas, tapi keselarasan dengan alam. Saetik mahi loba nyesa' (sedikit cukup, banyak bersisa).

Landasan atas model pertanian yang diolah berdasarkan pengetahuan lokal ini didasarkan atas prinsip adat yang merupakan inti dari pengetahuan mereka diantaranya adalah 'beuteung seubeuh, baju weuteuh, imah pageuh, pamajikan reuneuh' (perut kenyang, baju baru, rumah kokoh, istri dapat memberikan keturunan / anak) yang bermakna bahwa hasil tani dari menggarap lahan tidak perlu menunjukkan produktivitas tinggi yang menyebabkan lahan tersebut menjadi rusak, namun yang penting adalah bahwa hasil tani tersebut dapat mencukupi seluruh kebutuhan hidup, bahkan membuat hidup merasa tenteram yang ditunjukkan dengan konsep "pamajikan reuneuh" (masih bisa menghasilkan keturunan dan terpenuhi kebutuhan makannya). 
Kenyataannya memang menunjukkan bahwa sekarang ini semua incu putu (pengikut) abah sudah dapat memenuhi kebutuhan hidupnya, terbukti tidak ada incu putu yang meminjam padi terhadap abah (dari persediaan lumbung adat). Ini menunjukkan bahwa hasil tani penduduk sudah cukup untuk memenuhi hidup keluarga mereka. Hal ini bisa dipahami karena ada konsep lain dalam adat kasepuhan, yaitu larangan menjual padi / beras, sehingga hasil tani padi yang diperoleh mereka hanya dikhususkan untuk memenuhi kebutuhan hidup mereka. Adapun kebutuhan hidup lainnya, mereka peroleh dengan cara menjual hasil pertanian nonpadi berupa tanaman keras yang ditanam di talun atau palawija yang ditanam di sela-sela waktu menanam padi atau dari hasil ternak.

Konsep pertanian yang dijalankan oleh masyarakat adat kasepuhan ini tentu sedikit berbeda dari konsep pertanian modern yang berprinsip pada pencapaian produktivitas tinggi dari lahan pertanian. Kalau perlu menanam padi yang dapat dipanen 3-4 bulan dan lahan sawah ditanami 2-3 kali dalam setahun. Konsep ini menjadi kebijakan pertanian yang ditempuh oleh pemerintah Indonesia dalam rangka meningkatkan produksi pertanian, melalui program intensifikasi. Intensifikasi dilakukan dengan berbagai cara yang dapat meningkatkan produktivitas lahan.

Intensifikasi pertanian ditempuh dengan jalan penggunaan sarana produksi pertanian yang lebih baik seperti bibit unggul, pupuk dan obat-obatan yang diperlukan dalam rangka meningkatkan produktivitas pertanian, dan penggunaan teknik-teknik modern yang lebih efisien dikalangan petani. Intensifikasi lahan pertanian ini menjadi kebijakan yang paling mungkin dilakukan mengingat dari daratan Indonesia seluas 188.2 juta ha (Puslitbangtanak-Badan Litbang Pertanian, 2000), lahan tersedia menurut data dari Balai Besar Sumber Daya Lahan Pertanian (BBSDLP) hanya 30.67 juta ha. Lahan potensial untuk pertanian adalah "lahan yang secara biofisik, terutama dari aspek topografi / lereng, iklim, sifat fisika, kimia, dan biologi tanah sesuai atau cocok dikembangkan untuk pertanian”. Dalam hal ini, sesuai atau cocok berarti lahan tersebut secara teknis-agronomis mampu mendukung pertumbuhan tanaman dan atau perkembangan ternak secara optimal. Keterbatasan lahan pertanian, sementara jumlah penduduk tiap tahun terus bertambah, kebutuhan pangan terus bertambah menyebabkan pemerintah mengambil program intensifikasi sebagai kebijakan di bidang pertanian.

Selain dampak positif dari intensifikasi yaitu meningkatnya produktivitas, juga mempunyai dampak negatif terutama karena keinginan meningkatkan produksi ini menyebabkan lahan digarap terus menerus dengan tanaman yang sama (panen padi lebih dari satu kali) menyebabkan kebutuhan akan pupuk meningkat, yang dipenuhi melalui pupuk kimia. Tidak disadari semakin lama kebutuhan pupuk semakin lama semakin banyak dan menyebabkan berkurangnya unsur hara, belum lagi kebutuhan terhadap pengendalian hama penyakit yang tidak disadari berakibat pada pencemaran air. Produktivitas 
tinggi yang dihasilkan tersebut harus dibayar dengan biaya pertanian yang tinggi dan kerusakan terhadap lingkungan.

Jika dibandingkan dengan pertanian ala kasepuhan, pertanian intensifikasi lebih banyak kerugiannya. Namun persoalannya, pertanian kasepuhan hanya cukup untuk memenuhi kebutuhan hidupnya sendiri, tidak dapat memenuhi kebutuhan masyarakat Indonesia lainnya yang semakin hari penduduknya semakin bertambah sementara jumlah lahan pertanian semakin berkurang.

\section{Leuit vs Pasar}

Keunikan dalam masyarakat adat kasepuhan di Desa Sirna Resmi ini, padi dan beras tidak boleh dijual tapi boleh barter dengan benda lain disebut dengan istilah sosoroh. Padi memiliki arti yang sakral bagi warga kasepuhan lantaran dianggap sebagai titisan Nyi Pohaci (Dewi Sri) yang merupakan lambang kesuburan. Untuk memberikan penghargaan terhadap padi ini dibangunlah tempat khusus untuk menyimpan padi yang disebut leuit. Keyakinan mereka adalah 'kalau kita tinggal di dalam rumah, maka padi harus tinggal dalam rumah juga'. Ritual memasukkan padi ke dalam leuit merupakan bagian dari penghormatan terhadap padi seperti halnya pada saat padi mulai ditanam di sawah (ngaseuk) sampai memakan hasil panen pertama kali (nganyaran).

Bagi warga yang menjaga ketat tata cara mengolah tanah dan menanam padi terutama aturan hanya menanam padi satu kali panen setahun, peran leuit menjadi sangat penting. Kehadiran leuit ikut mengatur ketersediaan pangan di desa yang terpencil di tengah hutan itu. Di abah selaku pusat kasepuhan terdapat dua jenis leuit, yaitu leuit si jimat milik abah pribadi, dan leuit adat kasepuhan yaitu leuit adat cadangan untuk pangan incu putu abah. Setiap warga menyisihkan dua pocongan dari hasil panen yang dikumpulkan dimasukkan ke leuit adat kasepuhan. Warga juga mempunyai leuit sendiri, setiap keluarga minimal mempunyai sebuah leuit dengan kapasitas 2-10 ton gabah kering. Hasil panen dimasukkan ke dalam leuit dalam bentuk ikatan atau pocongan, yakni sekitar 400 pocongan per leuit. Adapun kebutuhan yang dikonsumsi setiap hari, biasanya warga memakai sisa dari hasil panen tahun lalu. Jika ada yang kekurangan, warga dapat meminjam padi dari 'leuit adat'. Padi tersebut dapat dibayar pada masa tuai yang akan datang dan tanpa bunga.

Terkadang leuit dapat dijadikan mahar (mas kawin) dalam kasus tertentu atau diwariskan kepada keturunan sebuah keluarga. Ketika mulai berkeluarga warga memproritaskan membangun leuit terlebih dahulu untuk memberikan rumah kepada Sang Dewi yang menjadi penopang hidup mereka.

Konsep "leuit" yang dalam pandangan masyarakat sebagai bentuk penghormatan pada "Dewi Sri", sebenarnya telah berfungsi sebagai ketahanan pangan untuk warga masyarakat tersebut. Dimana dengan konsep seperti ini masyarakat dipaksa untuk menyimpan padi di "leuit' dan mengatur cara konsumsi mereka. Konsep ini tentu sangat berbeda dengan konsep "pasar" ala 
kapitalisme. Pasar sebagai "mekanisme alokasi sumber daya yang terbatas, yang dalam konsep kapitalisme menjadi mesin pencipta kekayaan yang efektif. Kapitalisme dengan sifatnya yang serakah dan kejam telah menciptakan kekuatan pasar tak dapat berfungsi dengan efisien secara sosial. Kapitalisme dan hukum rimbanya "The survival of the Fittest (siapa yang paling kuat - dia yang menang)" mempunyat dampak sosial yang luar biasa terhadap terciptanya jurang (gap) antara si kaya dan si miskin. Kondisi ini tentu tidak akan terjadi di masyarakat kasepuhan. Kalaupun ada yang kaya dan yang miskin namun jurangnya tidak terlalu dalam. Si miskin di kasepuhan masih tetap bisa makan tiga kali sehari dan si kaya di kasepuhan tidak menjadi manusia yang mengekploitasi manusia lainnya.

Ada kepercayaan yang diyakini oleh masyarakat kasepuhan bahwa siapa yang menggarap lahan pertanian dan bermata pencaharian sebagai petani, tentu hidupnya tidak akan kekurangan. Kebutuhan untuk makan setiap hari akan dapat dicukupi dari hasil taninya. Kalaupun tidak cukup dapat meminjam padi kepada lumbung adat di kasepuhan. Kepercayaan tersebut semakin diyakini manakala ada contoh, bahwa orang yang paling kaya di kampung tersebut diukur dari luas lahan yang dimiliki, ternyata tidak menjamin bahwa hidupnya berkecukupan, karena yang bersangkutan tidak menggarap lahan sendiri melainkan di "paro-kan" kepada yang lain. Otomatis hasilnya hanya dapat setengahnya dan itu tidak cukup untuk makan sampai panen berikutnya.

Pada masyarakat kapitalis dengan mekanisme pasarnya, jurang yang kaya dan miskin semakin hari semakin dalam. Dari sekitar kurang lebih 7 milyar penduduk dunia hampir sekitar 2 milyar orang hidup dalam kemiskinan mutlak. Orang miskin ini semakin lama semakin bertambah banyak seiring dengan pertambahan penduduk yang begitu cepat. Kapitalisme dan pasar tidak memperhatikan kondisi seperti ini karena pasar dan kapitalisme mempunyai semboyan "Laissez-Faire" dimana kesejahteraan masyarakat bukan tanggung jawab pasar. Mekanisme pasar yang kapitalis tidak dapat memberi pemecahan jalan solutif yang bisa diterima atas masalah kesejahteraan manusia dan kelestarian lingkungan. Pasar tidak mengenal kata pemerataan dan keadilan. Berbagai macam barang kebutuhan yang tersedia di dalam pasar selalu menjadi milik orang yang paling mampu membelinya, bukan untuk orang yang membutuhkannya.

\section{Pengetahuan Hutan ala Adat vs Pengetahuan ala Departemen Kehutanan}

Kampung Sirna Resmi yang dikelilingi oleh hutan sekunder (kebun talun) sangat konstras dengan bukit gundul di sekitarnya. Di kebun talunnya, masyarakat menanami pohon buah-buahan seperti mangga, durian, rambutan serta pohon buah lainnya secara tumpang sari. Kampung mereka rimbun dan hijau. Ini menjadi satu sumbangan masyarakat kasepuhan dalam mengelola lingkungan alamnya. Menurut Uwa Ugis, penasehat (nagara) dari ketiga abah yang sekaligus ketua Kesatuan Adat Banten Kidul (SABAKI), mereka 
menanam kembali kawasan mata air dengan kayu dadap. Ia pun menegaskan bahwa kalau pun pemerintah dan Perum Perhutani dan pihak TNGHS mengaku tidak bisa lagi mengurus hutan, mereka mau mengambil alih urusan itu. Hukum adat menurut mereka amat efektif dalam menjaga lingkungan hutan mereka. Mereka memang menyaksikan, perubahan sangat besar dalam dua puluh tahun terakhir ini.

Masyarakat kasepuhan memandang kawasan Gunung Halimun sebagai wilayah adat mereka. Untuk itu mereka secara turun-temurun membagi wilayah adat itu dengan wewengkon (Zonasi). Zonasi menurut konsep kasepuhan adalah sebagai berikut (1) Hutan titipan, (2) Hutan tutupan, dan (3) Hutan garapan.

Masyarakat menggarap lahan pertanian pada lahan yang menurut mereka termasuk hutan garapan. Apabila lahan garapan sudah dianggap tidak subur lagi (sudah habis), maka masyarakat boleh menggarap lahan di hutan titipan / cawisan yaitu hutan leluhur yang dijadikan cadangan persediaan lahan. Namun tentu saja harus seizin abah yang berlandaskan pada adanya wangsit. Wangsit pembukaan lahan baru untuk garapan dan pemukiman pernah diterima oleh Abah Anom (ayahnya Abah Ugi) pada saat harus pindah dari Cipta Rasa ke Cipta Gelar yang letaknya persis di dalam Taman Nasional, padahal dalam konsep kasepuhan, daerah Cipta Gelar termasuk wewengkon hutan garapan. Perbedaan konsep ini menyebabkan perbedaan sikap dan perlakuan terhadap hutan.

Zonasi itu agak berbeda dengan zonasi yang dikeluarkan oleh pihak TNGHS. Misalnya zona rehabilitasi menurut TNGHS ternyata merupakan zona garapan menurut masyarakat lokal, sehingga karena letaknya berbeda menyebabkan pemahaman dan perlakuan terhadap hutan berbeda. TNGHS mempunyai konsep zonasi, yaitu: (1) zona inti, (2) zona rehabilitasi, (3) zona penyangga, (4) zona pemanfaatan, dan (5) zona rimba. Perbedaan zonasi tersebut juga disertai peta tata letak zonasi yang berbeda.

Seharusnya zona inti sama dengan wewengkon hutan tutupan. Namun kenyataannya peta zonasi menurut TNGHS berbeda dengan peta wewengkon menurut masyarakat adat kasepuhan. Bahkan sejak dikeluarkannya SK perluasan TNGH menjadi TNGHS menyebabkan akses masyarakat terhadap taman nasional bahkan di zona pemanfaatan pun menjadi tertutup. Hal ini didasarkan atas konsep pengelolaan hutan taman nasional. TNGHS merupakan kawasan pelestarian alam yang mempunyai ekosistem asli dan dikelola dengan sistem zonasi yang dimanfaatkan untuk tujuan penelitian, ilmu pengetahuan, dan pendidikan. Namun demikian, seharusnya, TNGHS juga bisa menunjang budidaya, budaya, pariwisata dan rekreasi yang bisa menaikkan derajat ekonomi masyarakat yang tinggal di sekitarnya. Bukan malah membuat kehidupan masyarakat sekitar menjadi semakin sengsara.

Kenyataannya, justru ketatnya peraturan dan larangan atas nama kelestarian Taman Nasional, dijadikan celah oleh oknum aparat dari instansi terkait untuk 
mengambil keuntungan demi kepentingan pribadi, dengan bersikap tidak konsisten dalam menjaga Taman Nasional secara sungguh-sungguh. Hal ini terjadi juga di TNGHS ketika seorang oknum membabat hutan pinus dan yang disalahkan adalah masyarakat sekitar. Kejadian tersebut membuat masyarakat menilai bahwa Taman Nasional sesungguhnya bukan untuk kelestarian tetapi hanya sebagai sarana untuk mendapatkan keuntungan sesaat bagi para oknum dan menyengsarakan masyarakat.

Padahal menurut Mc Kinnon et al (1993) bahwa keberhasilan pengelolaan Taman Nasional sangat bergantung pada penghargaan yang dapat diterima oleh masyarakat sekitar dari kawasan yang dilindungi. Dimana kalau sebuah kawasan yang dilindungi dipandang sebagai penghalang, maka masyarakat setempat dapat menggagalkan usaha pelestariannya. Tetapi bila dianggap sebagai sesuatu yang positif manfaatnya, maka masyarakat senantiasa akan sangat mendukung bahkan dapat menunjang kawasan yang dilindungi.

Melihat kenyataan di atas, sebenarnya baik masyarakat lokal maupun TNGHS mempunyai pengetahuan yang sama tentang pentingnya kelestarian hutan. Hanya saja pengetahuan tersebut diaplikasikan dalam bentuk yang berbeda terutama dalam memahami hutan sebagai bagian dari kehidupan dan tradisi nenek moyang. Hanya saja, kedua pihak ini mempunyai pandangan yang berbeda dalam hal melihat hutan. TNGHS memposisikan dirinya sebagai hutan yang harus lestari, sehingga tidak mentolerir kegiatan apapun yang dilakukan masyarakat di dalam kawasan. Masyarakat sendiri merasa berhak atas hutan yang diipandangnya sebagai tanah adat peninggalan para leluhur. Tentu saja hal ini tidak akan bertemu, karena keduanya mempunyai pandangan yang berbeda. Oleh karenanya, pengelolaan kawasan konservasi termasuk TNGHS perlu mengedepankan kepentingan dan kebutuhan masyarakat, misalnya diberi hak akses pada zona pemanfaatan. Namun konsep pemanfaatan pun berbeda. Jika masyarakat lokal memanfaatkan lahan untuk pertanian, maka zona pemanfaatan oleh TNGHS digunakan untuk kepentingan rekreasi, penelitian, atau kegiatan lain yang tidak mengganggu lahan. Perbedaan pemahaman ini menyebabkan TNGHS bersikap untuk menolak semua aktivitas masyarakat di sekitar hutan. Sikap inilah yang menyebabkan masyarakat kehilangan akses terhadap Taman Nasional. Padahal kawasan hutan yang dijadikan taman nasional tersebut sudah menjadi tempat hidup masyarakat adat / lokal jauh sebelum Taman Nasional terbentuk, sehingga awal konflik antara TNGHS yang menjunjung tinggi konservasi versus masyarakat adat kasepuhan yang memperjuangkan hak akses atas lahan peninggalan nenek moyangnya, pun terjadi.

\subsection{Dinamika Pengetahuan Lokal}

Pengetahuan masyarakat adat kasepuhan tentang pertanian, wewengkon hutan dan segala hal yang menghubungkan adanya keselarasan hidup manusia dengan 
alam / lingkungannya tidak selalu tetap, melainkan sedikit demi sedikit berubah seiring dengan kencangnya arus globalisasi.

Kenyataan saat ini, arus globalisasi telah menyebabkan perubahan gaya hidup. Perubahan yang paling mencolok adalah kepemilikan mobil dan handphone (HP). Abah Asep sudah mempunyai mobil. Namun dibandingkan dengan Abah Ugi, Abah Asep jauh tertinggal. Dulu saja waktu masih dipimpin oleh Abah Anom (ayahnya Abah Ugi) mempunyai 16 mobil, bahkan kabarnya mobil yang dipakai oleh Kepala Desa Sirna Resmi adalah pemberian dari Abah Anom. Bukan hanya Abah Asep tapi beberapa incu putu ada juga yang punya mobil. Selain mobil, fenomena HP sudah melanda warga masyarakat kasepuhan. Beberapa informan yang ditemui, umumnya menggunakan HP.

Perubahan yang terjadi di masyarakat Kasepuhan bukan hanya sebatas gaya hidup yang memang secara terbuka dibolehkan oleh adat melalui izin abah. Namun perubahan secara evolutif juga telah merubah tatanan budaya, misalnya dalam hal bentuk rumah juga telah terjadi pergeseran. Pada tahun 2003, Abah Asep pernah mengemukakan bahwa masyarakat yang termasuk incu putu abah dapat diketahui dari bentuk rumahnya yang beratapkan ijuk, dengan hiasan di atasnya yang dibedakan dari hiasan yang ada di atas leuit. Tahun 2009, pada saat studi lapang dilakukan, telah terjadi perubahan, bahwa rumah incu putu abah tidak selalu menggunakan atap ijuk.

Tradisi kasepuhan juga dicirikan dari cara mereka memasak yaitu keharusan menggunakan kayu bakar. Sampai saat ini tradisi ini masih ketat dijalankan, bahkan pembagian kompor dan tabung gas elpiji sebagai bentuk konversi dari minyak tanah, ditolak oleh warga karena tidak sesuai tradisi. Namun, beberapa incu putu abah yang juga sebagai pengurus desa, telah menggunakan gas elpiji untuk memasak. Desakan pemerintah untuk menggunakan gas elpiji, dan tertutupnya akses ke hutan untuk mencari kayu bakar, bukan tidak mungkin secara evolutif akan mengubah tradisi yang seperti ini.

Perubahan akibat globalisasi dan derasnya desakan pengetahuan modern, juga sudah mulai mengubah pengetahuan dan tata cara masyarakat dalam melakukan pertanian, misalnya sistem pertanian yang dilakukan oleh warga kasepuhan sebagian sudah menggunakan pandangan "rasional barat" yaitu penggunaan pupuk kimia pada pengolahan pertanian, walaupun sebelumnya hal ini dianggap tabu.

Tarik-menarik antara pengetahuan lokal yang berlandaskan pada tatali paranti karuhun berhadapan dengan sistem pengetahuan rasional barat yang sedikit demi sedikit secara evolutif sudah mulai merubah tatanan masyarakat, mulai disadari oleh para pemangku adat. Abah selaku penjaga tradisi menanggapi desakan pengetahuan modern tersebut dengan bijaksana namun tetap berada pada prinsip untuk tetap melaksanakan adat dengan tidak mengabaikan unsur sara dan nagara. Ketatnya norma-norma adat dijalankan dengan sanksi 
"kabendon" membuat beberapa pengetahuan pokok dalam hal pertanian selaku mata pencaharian utama masyarakat tetap terjaga dan belum berubah.

Kuatnya tradisi ini disebabkan hubungan timbal-balik antara masyarakat adat kasepuhan dengan lingkungannya sudah berlangsung secara terus-menerus dalam jangka waktu yang lama dan telah menghasilkan sesuatu tradisi yang digunakan oleh masyarakat untuk mengantisipasi perubahan lingkungan. Strategi adaptasi masyarakat terhadap perubahan lingkungan ini didasarkan atas pengetahuan lokal yang diturunkan dari generasi ke generasi. Pengetahuan lokal ini belum banyak berubah sejak zaman Abah Harjo (pendahulunya), walaupun dinamika lingkungan fisik dan sosial telah terjadi.

Realita sosial yang dialami masyarakat kasepuhan sekarang ini menunjukkan sedang terjadinya benturan antara kearifan / pengetahuan lokal dengan kearifan / pengetahuan pemerintah yang sarat dengan berbagai kepentingan politik. Upaya untuk melakukan perubahan taman nasional yang dalam konsep TNGHS dianggap sebagai upaya melestarikan alam, justru telah mengabaikan pengetahuan lokal masyarakat adat kasepuhan. Masyarakat terusir dari lingkungannya (kawasan Taman Nasional) dan kehilangan tanah garapan. Sementara untuk mengubah tatanan sendi-sendi kehidupan mereka yang sudah berlangsung ratusan tahun menjadi pranata-pranata yang baru tidak dimungkinkan. Bahkan upaya perluasan TNGHS ini telah memacu konflik antara masyarakat melawan pemerintah (TNGHS).

\subsection{Struktur Kekuasaan dan Konflik Pengetahuan}

Seperti umumnya desa lain di Indonesia, Desa Sirna Resmi dipimpin oleh seorang Kepala Desa yang dibantu oleh perangkat desa yang lain yang berfungsi menjalankan administrasi di tingkat desa. Selain ada lembaga desa, di Desa Sirna Resmi juga terdapat lembaga adat Kasepuhan. Lembaga kasepuhan ini mempunyai struktur sendiri dan mengatur masyarakat pengikutnya (incu putu), terutama dalam hal mata pencaharian pertanian.

Saat ini di Desa Sirna Resmi terdapat tiga (3) pusat kasepuhan, yaitu Kasepuhan Sinar Resmi, Kasepuhan Cipta Mulya, Kasepuhan Cipta Gelar. Secara historis, diketahui bahwa pada awalnya di Desa Sirna Resmi ini dulunya hanya ada satu kasepuhan yaitu berpusat di Cipta Rasa dengan ketua adat Abah Rusli kemudian dilanjutkan oleh Abah Harjo. Pada zaman Abah Harjo, ia membuka cabang di Sinar Resmi yang dipimpin oleh Abah Ujat yang sekaligus saat itu menjadi Kepala Desa Sirna Resmi. Diperlukan pengkajian lebih mendalam untuk mengungkap alasan pembentukan cabang kasepuhan di Sinar Resmi itu. Tetapi tampaknya itu berhubungan dengan Abah Harjo yang memiliki istri enam orang dan memiliki anak yang cukup banyak dari istriistrinya. Setelah Abah Harjo meninggal, maka kasepuhan diteruskan oleh Abah Ujat dengan pusatnya di Sinar Resmi itu. Abah Ujat adalah anak dari istri pertama Abah harjo. Tahun 2002, Abah Ujat meninggal dan kepemimpinannya diteruskan oleh Abah Asep sampai sekarang. 
Pada saat masih kepemimpinan Abah Ujat, Abah Anom (anak Abah Harjo dari istri yang ke enam) menerima wangsit untuk mendirikan kasepuhan di Cipta Rasa. Pada tahun 2002, kembali menerima wangsit yang memerintahkan kasepuhan Abah Anom untuk pindah ke Cipta Gelar, atau kembali ke asal nenek moyang dulu (kebo mulih pakandangan) dan akhirnya menetap / bermukim di Cipta Gelar sampai sekarang. Sepeninggal Abah Anom, kasepuhan Cipta Gelar dipimpin oleh Abah Ugi sampai saat ini.

Tahun 2003, Abah Uum (kakaknya Abah Ujat, anak pertama Abah Harjo dari istrinya yang pertama) yang pernah menjabat sebagai PJS Kasepuhan Sinar Resmi sebelum Abah Asep mau menjadi Abah, juga menerima wangsit untuk mendirikan kasepuhan yang berpusat di Cipta Mulya. Selain dari tiga kasepuhan di atas, masih ada kasepuhan-kasepuhan lain yang terdapat di Kabupaten Sukabumi, Kabupaten Lebak, dan Kabupaten Bogor. Kasepuhankasepuhan itu saat ini tergabung dalam Kesatuan Adat Kasepuhan Bantel Kidul (SABAKI).

Pemimpin tertinggi di kasepuhan adalah Abah, Kasepuhan Sinar Resmi sendiri dipimpin oleh Abah Asep. Istri abah disebut Ambu. Dilihat dari sejarah berdirinya kasepuhan, Abah Asep adalah pemimpin kasepuhan yang kesepuluh dicirikan dari makam. Proses penunjukan Abah Asep menjadi ketua adat mempunyai cerita tersendiri yang menarik. Sebelum menjadi abah, Abah Asep adalah seorang mahasiswa dan bekerja di Jakarta. Butuh tiga hari berturut-turut wangsit turun kepadanya untuk bersedia mengambil tanggung jawab sebagai abah karena konsekuensi seorang abah adalah menetap di Sinar Resmi. Itu membutuhkan pengorbanan yang sangat besar karena harus meninggalkan karir di Jakarta. Pada saat itu Ambu bekerja di Ancol sebagai koordinator rias artis. Tugas Ambu sendiri adalah mengabdi ke Abah. Namun dalam struktur kasepuhan, posisi dan tugas itu tidak tersurat. Sebagai pemimpin adat, keturunan abah memiliki strata lebih tinggi dari warga kasepuhan lainnya.

Dalam menjalankan tugasnya, Abah dibantu oleh staf ahli (penasehat) bidang agama dan negara (garis fungsional). Secara struktural, di bawah Abah terdiri dari wakil-wakil abah (kolot lembur, dukun dan penghulu), dan sekretaris. Tetapi tampaknya sekretaris adalah struktur baru yang dibentuk oleh Abah Asep karena tuntutan perkembangan zaman. Tugas sekretaris adalah mencatat jumlah incu putu (warga atau anggota kasepuhan) dan jumlah pemasukan padi pada saat seren tahun. Abah melalui sekretarisnya mempunyai catatan sendiri tentang berapa jumlah penduduk yang miskin yang berada di bawah kepemimpinannya. Selain itu, sekretaris mewakili Abah dalam berhubungan dengan dunia luar.

Staf ahli kasepuhan bidang agama (sara) dan nagara melengkapi tugas dan fungsi kasepuhan yang harus menselaraskan antara sara, nagara jeung mokaha, sehingga dalam prakteknya staf ahli ini menjalankan fungsi yang melengkapi 
tugas Abah. Fungsi dari masing-masing jabatan tersebut dapat dijelaskan sebagai berikut:

1. Sara' mengurus hal-hal yang berkaitan dengan agama, pemimpin Sara' adalah seorang Kyai yang bertugas mengurus hal-hal yang berkaitan dengan bidang keagamaan. Pemilihan Kyai berdasarkan keturunan dan menurut kepercayaan masyarakat kasepuhan terpilih dengan sendirinya melalui suatu mekanisme yang berbau mistis.

2. Mukaha, artinya salamat dipimpin oleh ketua adat dalam hal ini disebut Abah yang mempunyai tugas memimpin ritual / upacara-upacara adat Kasepuhan. Abah juga terpilih berdasarkan keturunan dan melalui mekanisme yang mistis juga (wangsit). Seorang Abah memperoleh berkah tersebut sebagai takdir, dia tidak dapat memilih untuk menjadi atau tidak menjadi seorang Abah.

3. Nagara, artinya perwakilan Abah untuk masalah kenegaraan, fungsinya untuk menjembatani kepentingan adat dengan pemerintahan desa maupun dengan dunia luar. Dipilih berdasarkan keturunan. Staf ahli bidang negara kasepuhan Abah Asep adalah Uwa Ugis.

Selain ada staf ahli, dalam menjalankan tugasnya Abah dibantu oleh Wakil Abah yaitu Kolot Lembur, Dukun dan Penghulu. Kolot Lembur adalah perwakilan Abah di tiap wilayah tertentu yang ditunjuk oleh Abah. Tugas yang harus dijalankan oleh Kolot Lembur adalah mewakili Abah dan mewakili incu putu. Di samping tugas itu, seorang Kolot Lembur juga wajib mengolah tanah abah yang berada di kampungnya dengan sistem bagi hasil. Kolot Lembur setara dengan kepala dusun di dalam pemerintahan desa. Di tiap dusun, jumlah Kolot Lembur ini tidak tentu, ada yang satu, dua, tiga bahkan lebih dari 3, tergantung dari jumlah incu putu di wilayah tersebut. Syarat untuk menjadi Kolot Lembur, adalah:

1. Dipercaya incu putu.

2. Mampu mewakili incu putu untuk menghadap Abah.

3. Berbobot (memiliki pengetahuan pertanian padi dan mempunyai lahan pertanian padi sawah atau huma), meskipun harta bukan jaminan untuk dipilih menjadi Kolot Lembur.

Saat ini Kasepuhan Sinar Resmi (Abah Asep) terdiri dari 99 Kolot Lembur yang terdapat bukan hanya di Desa Sirna Resmi tetapi juga di daerah-daerah lain. Sutiyoso, mantan gubernur DKI Jakarta, adalah Kolot Lembur Abah Asep di wilayah Jakarta. Pada dasarnya, keberadaan kolot lembur ini dalam rangka penguasaan wilayah kasepuhan, tidak secara fisik melainkan langsung pada individu-individu (incu putu).

Selain Kolot Lembur, Abah dibantu oleh dukun dan penghulu. Dukun di kasepuhan ini terdiri atas dukun khusus yaitu dukun manusia dan binatang serta dukun paraji yaitu dukun beranak atau melahirkan. Sedangkan penghulu adalah petugas yang berhubungan dengan hal-hal gaib, dan memimpin doa-doa pada acara-acara adat. Kalau Kolot Lembur dipilih berdasar kemampuan 
tertentu dan ditunjuk langsung oleh Abah, maka dukun dan penghulu adalah jabatan yang diwariskan. Artinya, hanya keturunan dari seorang dukun dan penghulu yang bisa menjadi dukun dan penghulu juga. Mekanisme pemilihannya sama seperti mekanisme terpilihnya seseorang menjadi Abah.

Selain memiliki wakil abah, dalam struktur kasepuhan juga terdapat jabatan tukang. Tukang-tukang itu bertugas dan bertanggung-jawab atas satu bidang pekerjaan tertentu, sebagai berikut:

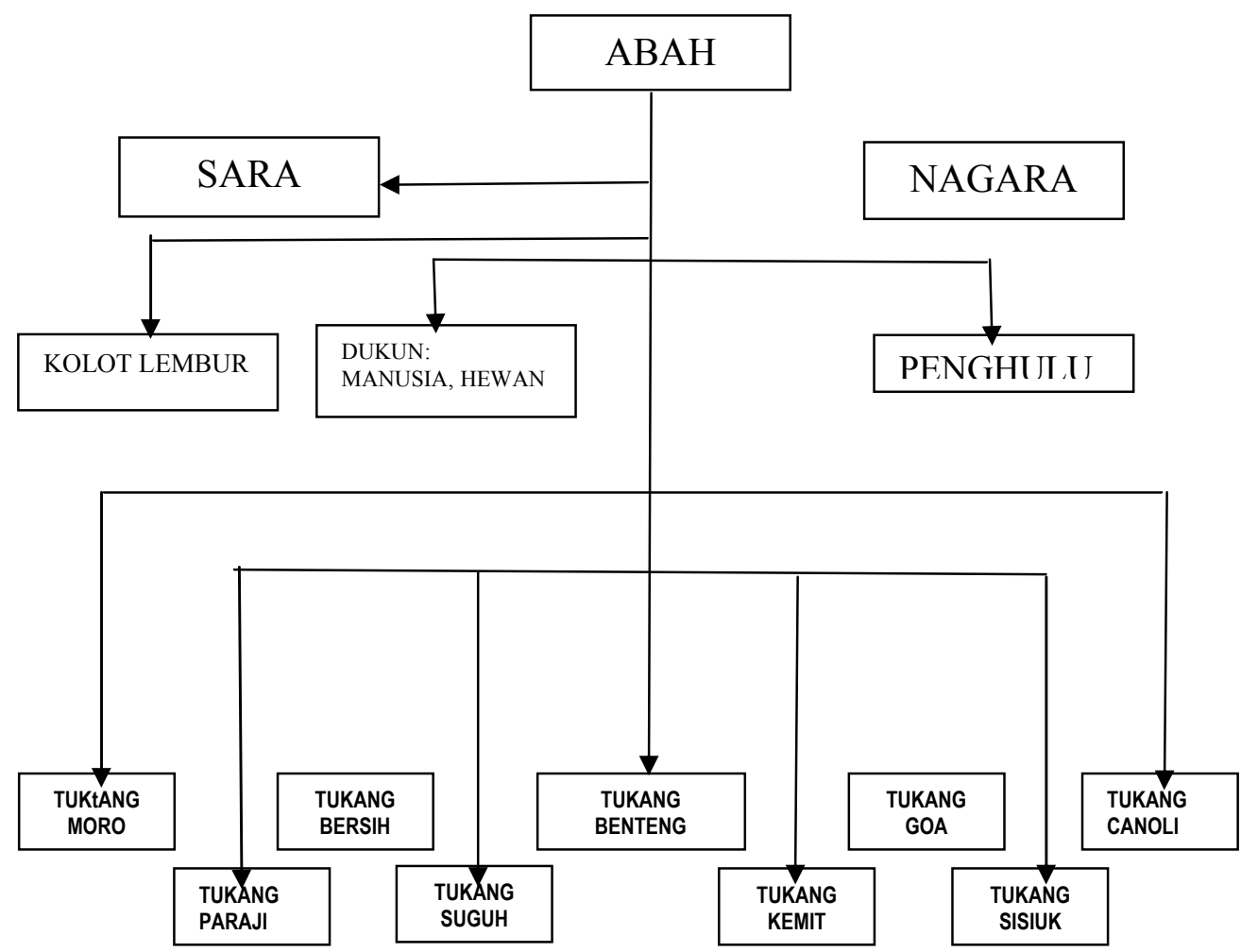

Gambar 2 Struktur kepemimpinan Adat Kasepuhan Sinar Resmi (Sumber: Arsip Sekretaris Kasepuhan Sinar Resmi, 2008)

Penjelasan masing-masing jabatan, sebagai berikut:

1. Tukang moro bertugas sebagai pemburu hewan kijang yang harus dipersiapkan pada setiap upacara seren tahun, setahun sekali sebanyak satu ekor; dan berburu babi hutan (hama talun / huma) setiap saat dibutuhkan jika mengganggu tanaman warga.

2. Tukang paraji terbagi dalam tiga bidang pekerjaan yaitu bertugas sebagai membantu melahirkan, menyunat anak, dan rias pengantin

3. Tukang bersih bertugas membersihkan rumah abah dan halamannya termasuk sebagai koordinator kebersihan untuk kerja bakti di desa 
4. Tukang suguh berfungsi sebagai tukang bangunan, yaitu yang membangun rumah abah (imah gede) dan bangunan lainnya yang dibutuhkan oleh adat

5. Tukang benteng bertugas membangun jalan dari batu dan pagar, baik di sekitar rumah abah sampai ke sawah atau talun

6. Tukang kemit mempunyai dua bidang tugas yaitu jaga malam lapor langsung ke abah dan sebagai penyedia kayu bakar yang bertanggungjawab langsung kepada Ambu

7. Tukang Goa berfungsi sebagai wakil Ambu apabila Ambu berhalangan dalam mengambil beras dari tempatnya / kamar beras (pandaringan), dengan menggunakan kemben putih, langsung bertanggungjawab kepada Ambu

8. Tukang Sisiuk bertugas menyiapkan prasmanan (makan bersama) apabila ada pesta atau tamu di rumah abah, langsung bertanggung jawab kepada Ambu

9. Tukang Canoli bertugas untuk memasak, langsung bertanggung jawab kepada Ambu.

Masing-masing tukang memiliki anak buah yang akan membantu dalam menjalankan tugasnya, jadi fungsi tukang adalah sebagai koordinator kegiatan. Pekerjaan sebagai tukang ini diwarisi dari orang tua masing-masing. Sehingga status sebagai tukang dapat disebut sebagai status turunan yang harus diterima, dan dalam menjalankan tugas sebagai tukang itu, mereka tidak diberi imbalan sedikit pun dan mengerjakan pekerjaan itu secara sukarela sebagai suatu kewajiban yang dibebankan kepadanya. Sepanjang kasepuhan berdiri, hal itu terjadi secara berkesinambungan. Selain tukang, Abah memiliki ajudan khusus yang disebut gandek. Gandek ini harus dari keturunan gandek juga, kalau bukan karena keturunan tidak akan kuat. Tugasnya adalah melayani seluruh keperluan abah dan mengawal kemana pun Abah pergi.

Selain mempunyai struktur, Abah juga mempunyai masyarakat / warga kasepuhan / pengikut yang disebut incu putu. Incu putu abah ini tersebar dimana-mana bukan hanya di Desa Sirna Resmi bahkan ada di daerah Lebak sampai Jakarta. Abah Asep sendiri memiliki sekitar 14.000 jiwa incu putu yang tersebar di mana-mana dan 99 perwakilan (Kolot Lembur / Rendangan). Satu lembur dipimpin oleh seorang Kolot Lembur. Kolot Lembur bukan turun temurun seperti struktur lain, melainkan orang yang paling dituakan di lembur tersebut. Adapun syarat untuk menjadi incu putu adalah hurif (motong ayam) dan disumpah secara adat (di rumah tiang ambu), seperti sumpah jabatan / pelantikan.

Secara struktur, keturunan Abah mempunyai strata lebih tinggi dibandingkan dengan incu putu dan jabatan struktur lainnya. Namun sebenarnya, ada struktur sosial lain yang mulai dipahami oleh masyarakat berdasarkan kepemilikan lahan / tanah, dalam hal ini adalah sawah. Tanah menjadi penting karena mata pencaharian utama masyarakat adalah bertani di sawah atau huma / ladang. Ada 
sawah milik pribadi dan sawah milik incu putu (adat) yang merupakan stok pangan digunakan untuk keperluan menjamu tamu dalam acara-acara ritual atau upacara adat. Desakan pengetahuan modern yang terus-menerus, bukan tidak mungkin suatu hari terjadi pergeseran struktur sosial masyarakat kasepuhan dimana tidak lagi melihat garis keturunan, melainkan pada kepemilikan mean of production (misalnya lahan pertanian).

Potensi konflik juga dapat terjadi akibat persaingan antar kasepuhan dalam meraih pengikut. Walaupun selama ini keanggotaan seseorang menjadi incu putu dari seorang Abah adalah pilihan yang tidak memaksa dan perpindahan kepengikutan dimungkinkan terjadi dari seorang Abah kepada Abah yang lain, dan sampai saat ini tidak menimbulkan masalah sosial sedikitpun. Setidaknya itu yang tergambar secara empiris. Hubungan antara masing-masing kasepuhan sekilas terlihat seperti harmonis walaupun tampak secara jelas ada persaingan dalam meraih pengikut.

Selain ada lembaga kasepuhan, juga ada lembaga desa (pemerintahan desa), yang dipimpin oleh seorang Kepala Desa bertugas menjalankan urusan administrasi kepemerintahan desa. Pemilihan kepala desa mengikuti pola-pola pemilihan yang berlaku di tempat lain. Hubungan antara desa dan kasepuhan ini sekilas seperti harmonis karena menjalankan fungsi yang berbeda di dalam kehidupan masyarakatnya. Bahkan sebenarnya kepala desa sendiri adalah incu putu kasepuhan tapi Kasepuhan Cipta Gelar. Namun tersirat dengan jelas bahwa dalam menjalankan tugasnya sebagai kepala desa, sering kali tersandung oleh peraturan adat, misalnya masalah pembagian gas elpizi yang terpaksa dikembalikan karena ditolak oleh warga / adat, padahal sebagai kepala desa seharusnya dapat menyukseskan program tersebut.

Pada prakteknya, Abah mempunyai pengaruh yang sangat besar terhadap kehidupan masyarakatnya, bahkan hampir semua kejadian / pengambilan keputusan keluarga dalam hal apapun selalu dikonsultasikan kepada Abah, misalnya ketika akan menikahkan anak, incu putu meminta izin terlebih dahulu kepada Abah baik secara langsung atau melalui Kolot Lembur. Termasuk dalam hal menggerakkan kerja bakti. Jika Abah yang meminta, maka semua warga akan melakukannya dengan sukarela. Perebutan pengaruh kekuasaan desa dan kasepuhan ini sangat kental terasa, namun karena sekretaris desa adalah juga sekretaris kasepuhan, maka yang terlihat hubungan desa dan kasepuhan adalah harmonis.

Jika diteliti lebih jauh, bahwa sebenarnya di Desa Sirna Resmi ada potensi konflik yang sangat kompleks, yaitu konflik antarkasepuhan, konflik antara kasepuhan dengan desa, konflik antara kasepuhan, struktur jabatan dan incu putunya. Potensi konflik ini bersifat laten, dan akan mencuat kepermukaan manakala desakan pengetahuan modern akibat globalisasi dan pembangunan terus-menerus menerpa Desa Sirna Resmi dan masyarakat adat kasepuhan. Selain potensi konflik tersebut, konflik besar dan sudah mulai terbuka sedang terjadi antara warga Desa Sirna Resmi dengan Taman Nasional Gunung 
Halimun - Salak (TNGHS). Bisa dipahami mengapa ketiga kasepuhan, desa dan warganya bersatu untuk saat ini karena mereka mempunyai masalah yang sama yang mempersatukan mereka untuk melawan TNGHS.

Konflik antara warga masyarakat Desa Sirna resmi dengan TNGHS terjadi karena perbedaan pengetahuan dalam mengelola lingkungan dan sumber daya alamnya. Warga desa selaku masyarakat adat kasepuhan telah memiliki pengetahuan lokal yang turun temurun dalam mengelola dan memperlakukan alam sehingga alam lestari, masing-masing orang dalam struktur kasepuhan mempunyai tugas sendiri-sendiri namun sebenarnya merupakan suatu kesatuan misi untuk menjaga kelestarian alam dan keharmonisan hidup manusia. Konsep tentang hablum minallah, minannas dan minal alam (selaras dengan Tuhan, dengan manusia lain dan dengan alam) diungkapkan oleh Abah Asep sebagai suatu pegangan utama dalam menjalankan hidup. 'Jika manusia merusak alam, alam punya caranya sendiri untuk menyeimbangkan dirinya, dan kalau itu terjadi maka manusia itu sendiri yang akan merugi', ungkap Abah Asep dalam menjelaskan pengetahuan lokal masyarakat kasepuhan dalam beradaptasi dengan alam. Konsep tentang wewengkon hutan yang membagi hutan ke dalam zonasi seperti halnya Taman Nasional menjadi piranti utama dalam menjaga kelestarian hutan di sekitarnya. Hutan boleh dimanfaatkan, digarap sesuai dengan zona peruntukannya, namun tetap dijaga kelestariannya.

Menurut keterangan yang didapat bahwa masyarakat sebenarnya juga sejak dulu telah melindungi kawasan Gunung Halimun karena masyarakat meyakini sumber air yang mengairi sawah-sawah mereka ditopang oleh keberadaan Gunung Halimun. Oleh karenanya dalam institusi adat, wilayah hutan adat dibagi ke dalam tiga sistem zonasi yaitu zona titipan, tutupan, dan garapan. Zona titipan difungsikan sebagai kawasan larangan dan cadangan untuk pemukiman; zona tutupan difungsikan sebagai hutan yang tidak boleh digarap bahkan diinjak yang berfungsi untuk mengatur kelestarian air dan lingkungannya; sedangkan zona garapan difungsikan untuk aktivitas pertanian dan talun yang dapat diambil kayunya untuk kebutuhan membangun rumah dan kayu bakar untuk kebutuhan sendiri. Kayu yang diambil di hutan ini hanya dipergunakan untuk kebutuhan sendiri dan tidak boleh diperjualbelikan, pengambilan, dan penggunaannya harus seizin abah.

Dengan menggunakan pemikiran dari Escobar (1999), bahwa pengetahuan lokal masyarakat kasepuhan tersebut dapat dipandang sebagai rezim alam organik, dimana pengetahuan lokal tersebut mengajarkan bahwa alam adalah juga makhluk hidup seperti manusia, keberadaannya untuk kemanfaatan manusia namun tetap harus dijaga kelestariannya karena alam merupakan titipan dari leluhur, sehingga pengaturannya juga diatur oleh leluhur. Pelanggaran atas aturan leluhur tersebut, seperti menebang pohon di leuweung titipan / tutupan maka akan berakibat "matak" kabendon (kualat) yang menyebabkan hilangnya nyawa dari badan. Sebagaimana Escobar (1999) kemukakan bahwa alam adalah pengalaman yang berbeda mengacu pada satu 
posisi sosial dan berbeda-beda dihasilkan oleh kelompok yang berbeda atau periode sejarah yang berbeda. Dengan begitu maka dalam konsep rezim alam organik, bahwa sebenarnya keberadaan hutan (Taman Nasional Gunung Halimun - Salak) adalah bentukan sosial dari masyarakat di sekitar hutan.

Untuk memahami konflik antara warga Desa Sirna Resmi dan TNGHS yang bertumpu pada perjuangan hak akses masyarakat atas tanah yang diklaim sebagai Taman Nasional sejak diterbitkannya SK Menteri Kehutanan Nomor 175/Kpts-II/ 2003 di tahun 2003 tentang perluasan Taman Nasional, sehingga yang tadinya lahan Perhutani sekarang menjadi taman nasional yang berimplikasi pada hak akses warga untuk dapat menggarap lahan di wilayah eks Perhutani tersebut. Untuk itu, perlu kajian historis terlebih dahulu untuk memahami konflik tersebut.

Secara historis, keberadaan penduduk di daerah ini sudah ada sejak zaman dahulu yaitu diperkirakan sejak tahun 1902. Wilayah kasepuhan, sejak tahun 1932 berpusat di Cicemet, kemudian tahun 1941 meluas ke wilayah Lebak Salak, Cijaha, Jeruk Nipis, Sodong / Lebak Nangka, dan Cisuren.

Taman Nasional Gunung Halimun (TNGH) ditetapkan berdasarkan SK Menteri Kehutanan Nomor 288/Kpts/II/1992 dan SK nomor 282/KP/H-II/1992 tanggal 26 Februari 1992 dengan luas 40.000 ha. Tahun 2003, diterbitkannya Keputusan Menteri Kehutanan Nomor 175/Kpts-II/2003 tentang Penunjukkan Kawasan Taman Nasional Gunung Halimun dan Perubahan Fungsi Kawasan Hutan Lindung, Hutan Produksi Tetap, Hutan Produksi Terbatas pada Kelompok Hutan Gunung Halimun dan Kelompok Hutan Gunung Salak seluas 113.357 Ha di Propinsi Jawa Barat dan Propinsi Banten menjadi Taman Nasional Gunung Halimun - Salak. Sejak SK perluasan ini, luas Taman Nasional Gunung Halimun - Salak menjadi 113.357 Ha. Sejak SK perluasan dikeluarkan, kurang lebih ada 300 perkampungan penduduk yang masuk ke dalam wilayah Taman Nasional, termasuk pemukiman dan lahan garapan penduduk Desa Sirna.

Sejak terbitnya SK perluasan tersebut, pihak pengelola TNGHS mengeluarkan perintah penghentian semua aktivitas pada areal yang masuk ke dalam kawasan TNGHS. Pemukiman dan areal garapan masyarakat yang masuk ke dalam kawasan juga harus ditinggalkan. Peristiwa perluasan kawasan ini merupakan momentum yang menandai awal terjadinya konflik antara masyarakat kasepuhan Sinar Resmi dan beberapa masyarakat desa sekitar dengan pihak pengelola TNGHS.

Pengelola TNGHS dalam konsepnya Escobar (1999) mewakili alam negara yang dalam prakteknya menjalankan cara-cara yang dilakukan oleh alam kapitalis dan alam tekno yang bersumber dari pengetahuan global modern tanpa mempertimbangkan keberadaan pengetahuan lokal masyarakat. Sehingga selalu melihat masyarakat lokal sekitar hutan sebagai penyebab kerusakan alam, sehingga keputusannya masyarakat keluar dari kawasan Taman Nasional. Alam 
negara mendasarkan pengetahuannya dari perspektif globalitas sebagaimana yang melanda negara-negara dunia ketiga. Bahkan saat ini isu lingkungan disinyalir sebagai bagian dari politik negara dunia ketiga dalam melakukan negosiasi untuk memperlakukan konservasi biodiversiti dan strateginya, dalam rangka memperoleh akses kedaulatan kepada sumber daya genetis; utang ekologis; dan negosiasi transfer keuangan dan teknis sumber daya pada dunia ketiga, dan alat negosiasi negara dunia ketiga dalam memperoleh transfer teknologi dan sumber daya keuangan untuk konservasi.

Sikap keras pengelola TNGHS terhadap masyarakat lokal yang menempati kawasan ini sedikit berbeda ketika menghadapi perusahaan perkebunan (Nirmala) yang letaknya persis berada pada enclave di TNGHS (di tengah hutan TNGHS). Secara status tanah memang berbeda. Perkebunan Nirmala sudah ditetapkan sebagai perkebunan jauh sebelum ada Taman Nasional, mereka memiliki surat-surat peruntukkan yang resmi, berbeda dengan masyarakat kasepuhan yang tidak mempunyai aspek legalitas atas tanah yang telah mereka kuasai selama berpuluh-puluh tahun.

Perkebunan Nirmala mewakili rezim pengetahuan alam kapitalis. Menurut rezim ini, para pemilik modal (kapitalis) adalah pihak yang mengkontruksi alam melalui intervensi kapital sedemikian sehingga alam tunduk pada kekuasaan kapitalis (lihat Kuswijayanti, 2007). Rezim alam kapitalis mendapat legitimasi dari Taman Nasional dan masyarakat setempat. Keberadaan perkebunan yang ada di enclave Taman Nasional ini menjadi pesona tersendiri dan dijadikan sebagai daya tarik pariwisata ke Taman Nasional, sementara masyarakat melihat perkebunan sebagai sumber nafkah keluarga yang dapat memberikan kesejahteraan. Namun karena keberadaan perkebunan ini termasuk ke dalam wilayah Kabupaten Bogor, letaknya jauh dari Desa Sirna Resmi, sehingga keberadaan perkebunan tersebut tidak memberi manfaat kepada warga masyarakat Kasepuhan.

Keberadaan perkebunan di tengah Taman Nasional menjadi sebuah cerita tersendiri dari ketidakadilan pengelola TNGHS dalam memperlakukan alam. Bentangan Gunung Halimun dan Gunung Salak yang dijadikan sebagai Taman Nasional mestinya dapat melingkupi seluruh kawasan baik itu kawasan pemukiman masyarakat maupun perkebunan jika keberpihakan murni atas alam. Namun jika kepentingan sudah mewarnai kebijakan maka yang terjadi, rezim alam organislah yang harus dikorbankan. Kondisi ini menempatkan keberadaan TNGHS sebagai sebuah krisis. Padahal menurut Escobar (1999) bahwa krisis alam adalah juga krisis tentang identitas alam. Makna dari alam dipastikan telah mengubah kelangsungan sejarah cenderung pada faktor budaya, sosioekonomi dan faktor politik. Menurut Raymond Williams dengan ringkas mengemukakan "gagasan tentang isi alam, bahkan tidak tercatat, suatu jumlah yang luar biasa dari sejarah manusia. (1980:68). Menolak pernyataan esensial tentang alam dari alam, dia melakukan penegasan ahwa beberapa pernyataan "gagasan tentang alam adalah gagasan tentang manusia. Gagasan 
manusia dalam mayarakat, sungguh-sungguh gagasan tentang macam-macam masyarakat (hal. 71). Alam menjadi pikiran tentang pemisahan dari orangorang dan menambah produktivitas pekerja, umpamanya, dihubungkan pada pandangan tentang manusia yang dibawa oleh kapitalisme dan modernitas. Mengikuti tradisi Williams, Barbara Bender menulis bahwa pengalaman manusia tentang alam dan pemandangan etnografi muncul dari pekerjaan ini dimana membaca sejarah kembali secara natural dari teks alam.

Semestinya, sebagaimana dikemukakan oleh Escobar, bahwa gagasan tentang alam adalah juga tentang manusia, sehingga penataan terhadap alam juga tidak terlepas dari menata manusia yang ada di dalamnya. Menata tidak berarti mengeluarkan, melainkan tetap dipelihara dengan rezim alam organiknya demi kepentingan kelestarian alam itu sendiri. Namun yang terjadi sebaliknya, sejak dikeluarkannya keputusan tentang TNGHS, pengelola TNGHS melakukan perintah penghentian aktivitas di dalam kawasan. Apa yang diperintahkan oleh pengelola kawasan tentu saja tidak diindahkan oleh masyarakat lokal yang sudah merasa bahwa mereka lahir, hidup, dan mencari nafkah di tempat ini bukan hanya satu generasi bahkan menurut cerita sudah 10 generasi sejak nenek moyang mereka pindah ke tempat ini. Tentu saja, kondisi demikian menempatkan masyarakat dan Taman Nasional berada pada kondisi konflik. Bahkan, penolakan masyarakat terhadap perluasan TNGHS melahirkan tindakan anarkis terhadap perusakan beberapa fasilitas di TNGHS oleh masyarakat yang terjadi pada tahun 2003. Camat Cisolok kemudian memfasilitasi penyelesaian konflik tersebut dengan memediasi pertemuan antara masyarakat dengan pihak pengelola kawasan. Hasil penting dari pertemuan tersebut adalah penandatanganan surat pernyataan oleh pihak pengelolaan kawasan yang berjanji akan merevisi peta kawasan.

Meskipun sudah dicapai kesepakatan untuk meninjau ulang peta kawasan namun kesepakatan itu tidak dilaksanakan oleh pihak pengelola kawasan. Dengan demikian masyarakat semakin tidak mengindahkan larangan untuk melakukan aktivitas di dalam kawasan. Kondisi ini kemudian melahirkan bentrokan antara warga dengan pihak pengelola kawasan pada tahun 2005. Konflik ini bermula dari penangkapan terhadap warga yang mengambil kayu di dalam kawasan oleh pihak pengelola kawasan. Alasan penangkapan adalah warga tersebut tidak memiliki SIT (Surat Izin Tebang) sedangkan menurut warga, mereka menebang pohon yang dulu mereka tanam sendiri. Konflik ini akhirnya dapat diselesaikan oleh Kepala Desa Sirna Resmi.

Untuk mengatasi ketegangan antara masyarakat dengan pihak pengelola kawasan, pihak pengelola kawasan sendiri sudah menginisiasi dua kali pertemuan pada tahun 2006 untuk membahas masalah kawasan. Kedua pertemuan tersebut diadakan di Pelabuhan Ratu dan dihadiri oleh perwakilan desa, perwakilan kasepuhan, perwakilan AMAN (Aliansi Masyarakat Adat Nusantara), pihak Pemerintah Daerah. Namun kedua pertemuan tersebut gagal membangun kesepakatan dan tidak membuahkan hasil. Belakangan ini, 
tepatnya pada tahun 2008 pihak pengelola kawasan menginisiasi pertemuan sosialisasi Rencana Strategis Pengelolaan Kawasan Lima Tahun ke depan yang akan diterapkan mulai pada tahun 2009 yang diselenggarakan di Bogor. Pertemuan ini dihadiri oleh perwakilan Pemerintah Daerah, perwakilan desa, perwakilan kasepuhan, perwakilan AMAN, dan pihak pengelola kawasan. Salah satu yang menjadi fokus pembahasan dalam pertemuan tersebut adalah rancangan pembagian zonasi yang kemudian ditolak oleh pemerintah daerah dan masyarakat karena dianggap tidak memberikan solusi terhadap sengketa kawasan antara masyarakat dengan pihak pengelola kawasan. Menurut keterangan yang diperoleh, warga sudah menyatakan perang jika RENSTRA 5 tahun TNGHS diterapkan. Hal senada juga sudah dikemukakan oleh perangkat Desa Sirna Resmi dan Pimpinan Kasepuhan Sinar Resmi.

Dalam konflik kawasan yang melibatkan pelestarian lingkungan (biodiversity), banyak pihak akan terlibat atau melibatkan diri di dalamnya. Hal ini terkait dengan apa yang dikemukakan Escobar (1998) bahwa biodiversity diproduksi oleh institusi-institusi yang dominan, terutama sekali oleh Bank Dunia dan NGOs lingkungan di selatan (misalnya WCU, WRI dan WWF) dan didukung oleh negara-negara G-7. Dasarnya adalah sebuah representasi utama dalam "ancaman terhadap biodiversity" yang mengakibatkan kehilangan habitat, introduksi spesies pada habitat yang asing, dan fragmentasi pada penurunan habitat". Selanjutnya institusi-institusi yang dominan tersebut menawarkan seperangkat preskripsi untuk konservasi dan keberlanjutan penggunaan sumber daya pada dunia internasional, nasional dan level lokal; dan mendukung mekanisme manajemen biodiversity yang tepat, termasuk riset ilmiah, konservasi in-situ dan ex-situ, perencanaan biodiversity nasional, dan pendirian mekanisme yang tepat untuk kompensasi dan manfaat ekonomi dari sumber daya biodiversity, terutama melalui hak milik intelektual. Diskursus dominan ini dipromosikan secara aktif dari suatu situs yang bervariasi dan melalui pelipatgandaan akademik, institusional, manajerial, dan praktik politik, yang berasal dari pengetahuan (sains) yang dominan, kapital, dan manajemen.

Begitupun yang terjadi di TNGHS, keberadaan institusi yang dominan juga mewarnai konflik yang ada di TNGHS, baik institusi internasional maupun nasional, baik yang mendampingi TNGHS maupun yang secara terangterangan memposisikan diri sebagai pembela hak masyarakat. Ada beberapa komponen yang terlibat baik secara langsung maupun tidak langsung dalam konflik TNGHS versus masyarakat lokal, diantaranya pihak pemerintah Kabupaten Sukabumi, AMAN, APDESI (Asosiasi Pemerintah Desa Indonesia), Lembaga Kesatuan Adat Banten Kidul, JICA (Japan International Cooperative Agency), dan RMI (Rimbawan Muda Indonesia). Masyarakat dalam posisi yang berkonflik langsung dengan pihak pengelola kawasan didukung oleh Kepala Desa dan Pimpinan Kasepuhan. Kepala desa kemudian menggalang dukungan dari pihak pemerintah kabupaten dan APDESI sedangkan kasepuhan menggalang dukungan dari AMAN dan Lembaga Kesatuan Adat Gunung Kidul. JICA dan RMI tidak memposisikan diri sebagai kekuatan pendukung 
pada salah satu pihak yang terlibat konflik. JICA dengan konsep "Model Kampung Konservasi (MKK)"-nya mencoba membantu TNGHS dalam mereboisasi kembali hutan yang gundul melalui konsep partisipasi masyarakat, dan melakukan pengembangan usaha ekonomi produktif untuk masyarakat di dalam kawasan. Melalui MKK, pengelola kawasan TNGHS mencoba membina kelompok-kelompok masyarakat yang dihimpun melalui wadah MKK (Model Kampung Konservasi) yang didukung oleh pendanaan dari JICA. Namun konsep ini belum sepenuhnya diterima oleh masyarakat mengingat pelarangan akses terhadap sumber daya hutan (menggarap lahan di eks Perhutani) tetap diberlakukan sehingga kecurigaan terhadap konsep JICA dalam upaya membodohi masyarakat disadari oleh beberapa masyarakat, sehingga dari 5 kelompok bentukan JICA di tahun 2004, yang masih terbentuk tinggal 3 kelompok lagi.

RMI memfasilitasi pemetaan partisipatif untuk wilayah adat Kasepuhan Sinar Resmi, pelaksanaan program penanaman pohon di sekitar sumber mata air, penyelenggaraan pendidikan kritis bagi masyarakat desa, bahkan RMI juga pernah menginisiasi pertemuan antara masyarakat dengan pihak pengelola kawasan namun gagal karena pihak pengelola kawasan tidak berkenan hadir.

Secara rinci, jaringan aktor yang terlibat dalam konflik antara masyarakat dengan pihak pengelola Taman Nasional Gunung Halimun dapat digambarkan pada Gambar 3.

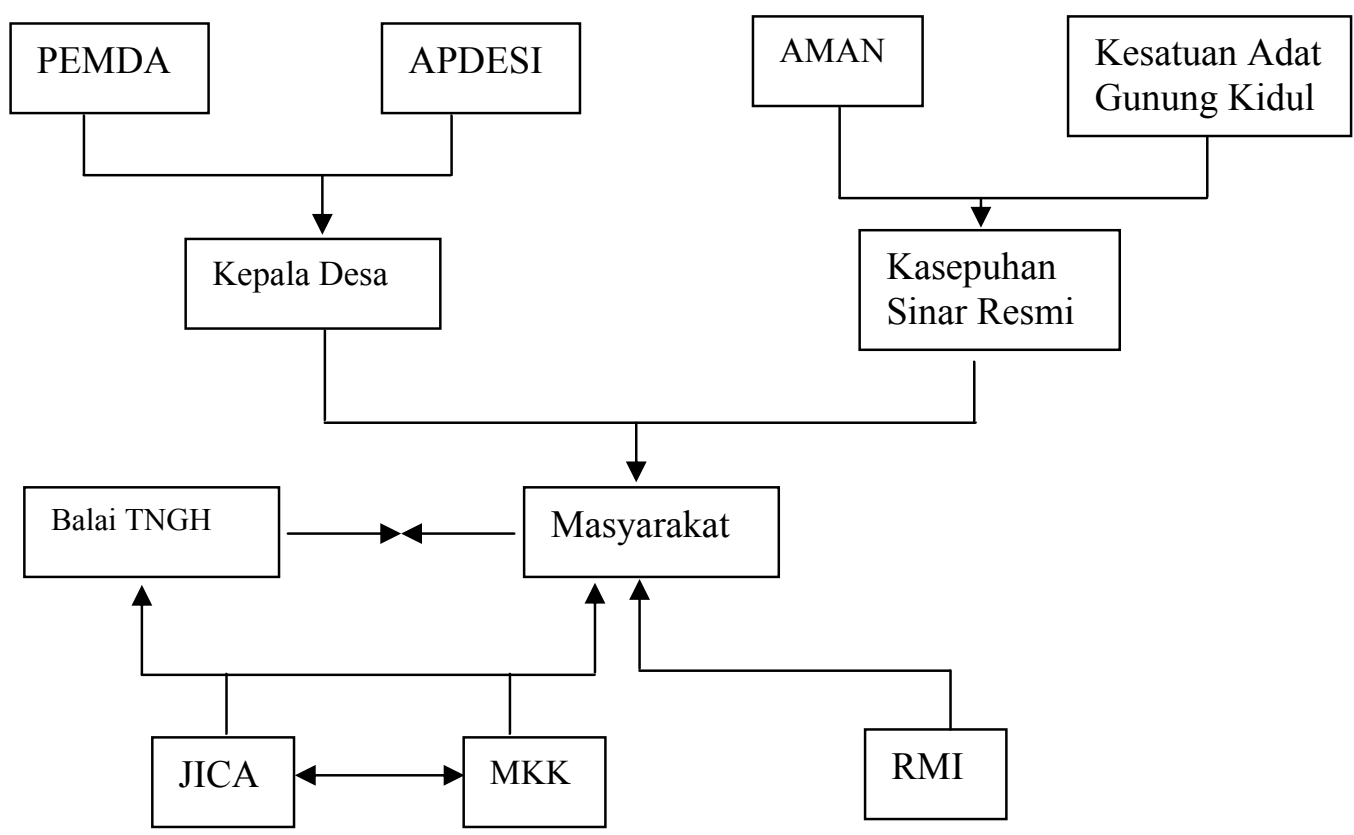

Gambar 3 Jaringan aktor dalam konflik masyarakat versus Balai Taman Nasional Gunung Halimun 
Perjuangan masyarakat melawan TNGHS adalah perjuangan untuk memperoleh hak akses, hak hidup atas tanah yang sejak dulu mereka tempati jauh sebelum ada Taman Nasional. Dengan demikian, perjuangan masyarakat mempertahankan wilayah yang diklaim sebagai bagian dari wilayah adat mereka terkait dengan keberadaan lahan-lahan garapan yang berfungsi menopang hidup mereka. Lahan-lahan garapan tersebut lebih dimaknai sebagai "sosial insurance" ketimbang status lahan. Dengan merujuk pada institusi adat yang mereka miliki bahwa lahan yang tidak digarap selama tiga tahun maka orang lain boleh menggarapnya. Intensitas masyarakat mengelola lahan garapan tidak tercermin dari upaya untuk memper-tahankan status kepemilikannya namun terpusat pada kemampuan lahan tersebut dalam memenuhi kebutuhan hidup mereka. Oleh karenanya, sewaktu Perhutani beroperasi di atas kawasan yang sebenarnya dalam pemahaman masyarakat me-rupakan bagian dari wilayah adat mereka tidak terlalu dipersoalkan karena mereka masih tetap bisa menggarapnya dan memperoleh hasil dari lahan garapannya.

Ketakutan pengelola TNGHS terhadap perusakan yang akan diakibatkan oleh masyarakat sangat tidak beralasan mengingat masyarakat sendiri (kasepuhan) mempunyai pengetahuan lokal yang mengatur pengelolaan alam mengikuti sistem zonasi yang telah diatur oleh institusi adat. Menurut narasumber sebenarnya tidak akan ada masalah dan masyarakat pasti akan mematuhinya. Selama lembaga adat kasepuhan dan masyarakat adat (incu putu) tetap menganut dan mengakui keberadaan kasepuhan beserta adat mengenai wangsit, wewengkon, leuit, dan kabendon tetap dipahami dan dijalankan, maka hutan tetap akan lestari.

\section{Kesimpulan Dan Saran}

\subsection{Kesimpulan}

Bentuk-bentuk pengetahuan lokal yang menjadi ciri khas dari masyarakat kasepuhan Abah Asep (Sinar Resmi) ditandai dengan beberapa pemahaman terhadap hubungan antara manusia dengan alam dan bagaimana manusia mengelola sumber daya alam. Pengetahuan ini pulalah yang mengarahkan pola adaptasi manusia terhadap alam dan sistem nafkah keluarga yang bertumpu pada pertanian. Pemahaman masyarakat tentang Ibu Bumi, Bapak Langit dan Guru Mangsa yang mensadarkan segala sesuatu dalam hal mengelola lahan pertanian pada keberadaan bumi yang diperlakukan seperti ibu (manusia) sehingga pengelolaan bumi mempertimbangkan kemampuan bumi. Seperti halnya Ibu, bumi tidak hanya boleh melahirkan (panen) satu kali. Penghormatan terhadap Dewi Sri melengkapi konsep Ibu Bumi yang identik di dalamnya adalah Dewi Sri (padi). Begitupun dengan konsep Bapak Langit dan Guru Mangsa yang menyandarkan diri dalam mengambil keputusan untuk mengolah lahan sesuai apa yang diajarkan oleh alam semesta melalui bintang 
kidang dan kerti serta berguru kepada waktu dimana hanya bulan-bulan tertentu saja yang boleh (hak) manusia sedangkan bulan yang lain diperuntukkan bagi makhluk lain (hama), karena semua makhluk adalah makhluk Tuhan, yang masing-masing diberi hak atas hidup.

Pengetahuan masyarakat tentang pertanian ini semakin dilengkapi dengan keberadaan "leuit" (lumbung padi) sebagai pranata untuk ketahanan pangan, dimana berfungsi menyimpan hasil panen padi yang tidak boleh dijual melainkan hanya untuk dikonsumsi sendiri. Apabila hasil panen kurang, maka leuit adat akan menjadi solusi untuk mengatasi kekurangan pangan.

Bentuk pengetahuan lain masyarakat kasepuhan yang menjadi ciri dalam beradaptasi dengan lingkungan demi kelestarian dan kemanfaatan lingkungan adalah adanya konsep wewengkon yang dilandaskan atas pembagian hutan ke dalam tiga zonasi, yaitu leuweung tutupan, leuweung titipan dan leuweung garapan.

Konsep pengetahuan lokal tentang relasi manusia dengan alam dan bagaimana manusia memperlakukan alam terangkum dalam kosmologi kasepuhan dalam pancer pangawinan. Pancer berarti lulugu atau asal usul, sementara pangawinan berarti ngawin yaitu membawa tombak dalam upacara perkawinan. Upacara perkawinan pun dipandang sebagai menyatunya manusia dengan tanah yang menghidupinya (lihat, Kusnaka, 1989). Selain itu, masyarakat kasepuhan harus secara selaras dapat menempatkan dan menjalankan sara, nagara jeung mokaha. Sara adalah agama, nagara adalah pemerintahan dan mokaha adalah keselamatan atau kasepuhan. Sara, nagara dan mokaha harus bersatu. Setiap keputusan yang diambil oleh kasepuhan harus mengacu pada prinsip: 'kudu nyanghulu ka hukum, nunjang ka nagara, mufakat jeung balarea' (harus mengacu kepada hukum, mendukung negara, mufakat dengan orang banyak).

Dalam perkembangannya, pengetahuan lokal tersebut mengalami terpaan yang begitu kuat dari derasnya arus urbanisasi yang ditandai oleh beberapa perubahan fisik, baik dalam hal gaya hidup, kepemilikan benda maupun perubahan bentuk rumah. Proses evolusi kebudayaan sedang terjadi. Perubahan tersebut juga mulai berdampak pada pengetahuan lokal yang mulai terkikis dengan adanya beberapa warga yang mulai menggunakan pupuk kimia untuk mengolah lahannya. Namun, peran aktor dalam hal ini abah dan struktur kasepuhan lainnya sebagai penjaga adat tetap mempertahankan keberadaan tradisi pengetahuan lokal tersebut sehingga sampai saat ini masih sesuai dengan tradisi awalnya. Bukan tidak mungkin di kemudian hari akan mengalami perubahan secara evolutif, jika desakan pengetahuan modern dan pembangunan terus mempersempit ruang gerak lembaga adat kaasepuhan ini.

Mengacu pada konsep Escobar (1999), pengetahuan lokal dalam mengelola sumber daya alam, terutama dalam hal memperlakukan hutan dapat dipandang sebagai rezim alam organik. Sejak diberlakukannya SK Menteri Kehutanan tentang perluasan TNGHS, masyarakat lokal dengan alam organiknya sedang 
berhadapan dengan pengelola TNGHS selaku rezim alam negara yang dalam prakteknya bertumpu pada pengetahuan kapitalis dan tekno, dalam memperjuangkan hak akses atas tanah.

Perlakuan yang tidak adil dari rezim negara (pengelola taman nasional) terhadap masyarakat dengan alam organisnya dan terhadap Perkebunan Perusahaan Nirmala (enclave) dengan alam kapitalisnya yang tetap diberi ruang, diakui kepemilikan dan penguasaannya walaupun secara lokasi perkebunan tersebut berada di tengah-tengah TNGHS, telah menyulut perjuangan masyarakat adat kasepuhan semakin gencar. Perjuangan tersebut didasari atas motivasi yang kuat untuk melindungi hutan dibandingkan pihakpihak lain karena menyangkut keberlanjutan kehidupan mereka. Masyarakat adat memiliki pengetahuan asli bagaimana memelihara dan memanfaatkan sumber daya hutan yang ada di dalam habitat mereka. Masyarakat adat memiliki hukum adat untuk ditegakkan, memiliki struktur kelembagaan yang kuat dengan elemen-elemen struktur yang menjaga adat sesuai tugas dan fungsinya.

\subsection{Saran}

Saran yang dapat disampaikan untuk dapat menjaga keberlangsungan pengetahuan lokal (alam organik) dan menyelesaikan konflik bertumpu pada perlakuan yang adil bagi masyarakat adat dan Taman Nasional sehingga alam organik dan alam negara termasuk di dalamnya alam kapitalis dan alam tekno dapat berlangsung secara harmonis (koeksistensi).

Adapun solusi yang ditawarkan oleh peneliti untuk mengakhiri konflik dapat ditempuh dengan cara :

1. Pihak pengelola kawasan memberlakukan sistem zonasi Taman Nasional Gunung Halimun mengikuti sistem zonasi wilayah adat mereka.

2. Menjadikan wilayah adat kasepuhan sebagai "enclave sistem budaya" bagian dari Taman Nasional yang dijadikan sebagai cagar budaya dan sebagai bagian dari promosi pariwisata ke Taman Nasional, dengan tetap memberi ruang kepada masyarakat untuk tetap dapat mengelola lahan garapan mereka yang telah dikelola sudah sejak lama, dan dibatasi tidak memperluas lahan ke tempat yang lain. 


\section{Daftar Pustaka}

Adimihardja, K. 1989. Manusia Sunda dan Lingkungannya: Suatu Kajian Mengenai Kehidupan Sosiobudaya dan Ekologi Komuniti Kasepuhan Desa Sirnarasa Jawa Barat Indonesia. Thesis Ph.D. Tidak dipublikasikan. Fakulti Sains Kemasyarakatan dan Kemanusiaan. University Kebangsaan Malaysia. Bangi.

Anonymous, 2009. Hak-hak Masyarakat Adat dan Masalah serta Kelestarian Lingkungan Hidup di Indonesia. http://www.tempointeraktif.com. Diakses pada tanggal 29 Januari 2009.

Adeney, B. T. 1995. Etika Sosial Lintas Budaya. Kanisius. Yogyakarta.

Ayatrohaedi, 1986. Kepribadian Budaya Bangsa (Local Genius). Pustaka Jaya. Jakarta.

Berkes, F. et.al., 1995. Traditional Ecological Knowledge, Biodiversity, Resiliece, and Sustainability, dalam Perring, C.A., et. al., 1995, Biodiversity Conversation. The Netherland. Kluwer Academic.

Castels, S., 2001. Studying Social Transformation, International Political Science Review, Vol. 22/1, 2001.

Dharmawan, A. H. 2006. Pendekatan-Pendekatan Pembangunan Pedesaan dan Pertanian: Klasik dan Kontemporer. Makalah yang disampaikan pada Acara "Apresiasi Perencanaan Pembangunan Pertanian Daerah bagi Tenaga Pemandu Teknologi Mendukung Prima Tani", diselenggarakan di Hotel Jaya-Raya, Cisarua Bogor, 19-25 November 2006.

, 2007. Dinamika Sosio-Ekologi Pedesaan: Perspektif dan

Pertautan Keilmuan Ekologi Manusia, Sosiologi Lingkungan dan Ekologi Politik, dalam Sodality: Furnal Transdisiplin, Sosiologi, Komunikasi dan Ekologi Manusia, Departemen KPM IPB, Volume 1 Nomor 1 April 2007.

, 2007. Otoritas Lokal dalam Pengelolaan sumber daya Alam: Menatap Otonomi Desa dalam Perspektif Sosiologi Pembangunan dan Ekologi Politik. Makalah yang disampaikan pada "Seminar dan Lokakarya Menuju Desa 2030" diselenggarakan oleh PKSPL, PSP3IPB dan P4W LPPM IPB, dilaksanakan di Kampus Manajemen Bisnis IPB Gunung Gede, Bogor 9-10 Mei 2007.

Escobar, A. 1998. Whose Knowledge, Whose Nature? Biodiversity, Conservation, and the Political Ecology of Social Movement, dalam Fournal of Political Ecology, Vol. 5, 1998. 
, 1999, After Nature: Steps to an Antiessentialist Political Ecology, dalam Current Anthropology, Vol. 40/1, 1999. , 2005. Imagining a Post-Development Era dalam Edelman, $M$ and Haugerud, A. (eds.), 2005. The Anthropology of Development and Globalization: From Classical Political Economy to Contemporary Neoliberalism. Blackwell. Malden and Oxford.

Friedman, J. 1999, Indigenous Struggles and the Discreet Charm of the Bourgeoisie, dalam fournal of World System Research, Vol. 2, 1999.

Giddens, A. 1984. The Constitution of Society: Outline of the Theory of Structuration. Cambridge. Polity Press.

Geertz, C. 1963. Agricultural Involution: The Processes of Ecological Change in Indonesia. University of California Press. Berkeley.

Geriya, S. S. 2009, Menggali Kearifan Lokal untuk Ajeg Bali dalam http://www.balipos.co.id. Diakses pada tanggal 21 Januari 2009.

Gobyah, I. K., 2009. Berpijak pada Kearifan Lokal dalam http://www. balipos.co.id. Diakses pada tanggal 17 Januari 2009.

Hobart, M. 1993. Introduction: the Growth of Ignorance? dalam M. Hobart (ed), An Anthropoligical Critique of Development: the Growth of Ignorance. Routledge. London.

Koenjaraningrat, 1990. Kebudayaan Mentalitas dan Pembangunan. Gramedia. Jakarta.

, 1999. Manusia dan Kebudayaan di Indonesia. Penerbit Djambatan. Jakarta.

Lauer, Robert H., 1993. Perspektif tentang Perubahan Sosial. Alih bahasa : Alimandan. Rineka Cipta. Jakarta.

Niels Mulder , 1985. Pribadi dan Masyarakat di Jawa. Sinar Harapan. Jakarta.

Nygren, A., 1999, 'Local Knowledge in the Environment-Development Discours', dalam Critique of Anthropology, Vol. 19/3, 1999.

Polak, J.B.A.F., 1996. Sosiologi : Suatu Pengantar Ringkas. Ikhtiar. Jakarta.

Prasodjo, Nuraini W., Pengetahuan Lokal dalam Pengelolaan Daerah Aliran Sungai Citandui. Makalah.

Raharjo, 2004. Pengantar Sosiologi Pedesaan dan Pertanian. Yogyakarta: Gadjah Mada University Press.

Robinson, W. I., 2001. 'Social Theory and Globalization: The Rise of Transnational State', dalam Theory and Society, Vol. 30, 2001.

Sanderson, Dwight, 1952. Rural Sociology and Rural Organization. Hohn Wiley \& Sons. New York. 
Shiva, Vandana, dkk., 1993. Keragaman Hayati: Perspektif Sosial dan Ekologi. Konphalindo. Jakarta.

Silitoe, P. 1998. The Development of Indigenous Knowledge: A New Applied Anthropology. Current Anthropology, Vol. 39/2.

Smith. T. Lynn and Paul F. Zopf, 1970. Principles of Inductive Rural Sociology. Philadelphia. F.A. Davis Company. USA.

Warren, D.M., Brokensha, D. and Slikkenveer, L.J., eds. 1992. Indigenous Knowledge Systems: The Cultural Dimensions of Development. Kegan Paul International. London. 
190 | Rahmawati, R. et. al. Pengetahuan Lokal Masyarakat Adat Kasepuhan 